\title{
Dynamic in situ confinement triggers ligand-free neuropeptide receptor
}

\section{signaling}

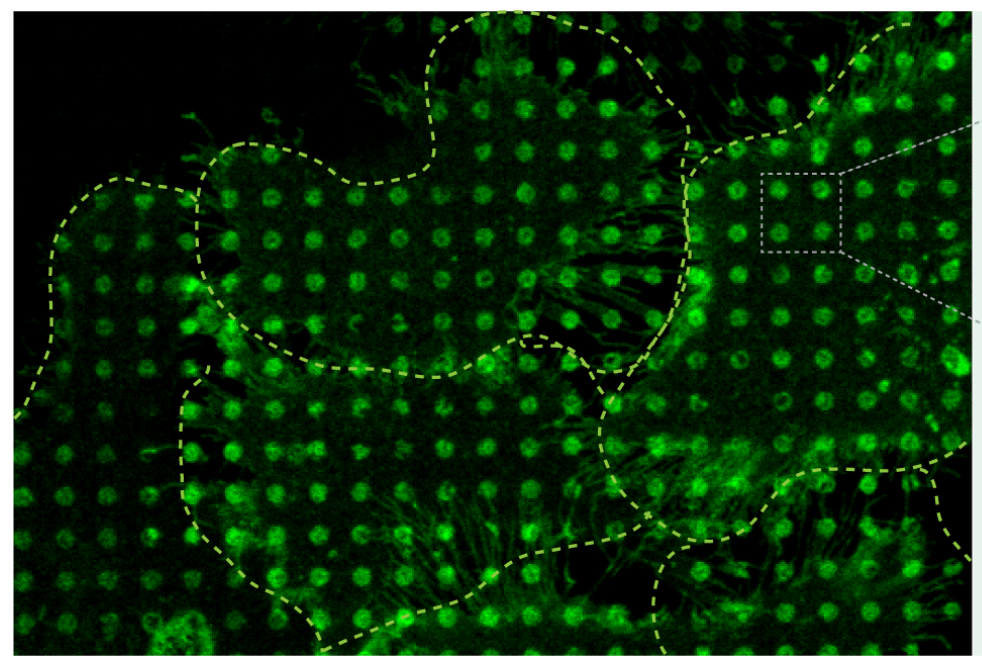

Dynamic in-situ receptor confinement

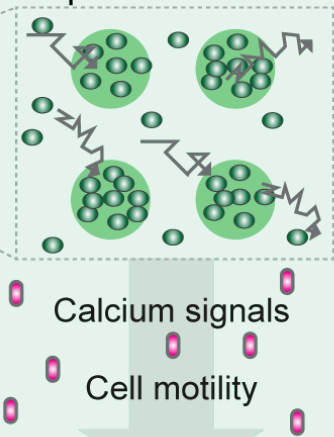

Ligand-independent cell response 


\section{Abstract}

17 Membrane receptors are central to cell-cell communication. Receptor clustering at the plasma

18 membrane modulates physiological responses, and microscale receptor organization is critical

19 for downstream signaling. Spatially restricted cluster formation of the neuropeptide $Y_{2}$

20 hormone receptor $\left(Y_{2} R\right)$ was observed in vivo; however, the relevance of this confinement is

21 not fully understood. Here, we controlled $Y_{2} R$ clustering in situ by a multivalent chelator

22 nanotool in prestructured matrices. Fast $\mathrm{Y}_{2} \mathrm{R}$ enrichment in microscale arrays triggered a

23 ligand-independent downstream signaling determined by an increase in cytosolic calcium, cell

24 spreading and migration. We reveal that ligand-independent signaling by confinement differs

25 from ligand-induced activation in the recruitment of arrestin-3 as downstream effector, which

26 was recruited to confined regions only in presence of the ligand. The employed multivalent nanotool facilitated a dynamic receptor enrichment with high exchange in the confined regions, comparable to microscale condensates. This concept enables in situ organization of membrane receptors and the exploration of ligand-independent receptor signaling.

31 Keywords: G protein-coupled receptors / membrane organization / membrane proteins /

32 phase segregation / receptor clustering 


\section{Introduction}

34 Cells translate stimuli into biochemical signals through membrane receptors controlling multiple aspects of cell behavior, including migration (Kupperman et al., 2000; Stallaert et al., 2018), differentiation (Li \& Rudensky, 2016; Luther \& Cyster, 2001), apoptosis (Scott et al., 2009), as well as infectious diseases and cancer (Boncompain et al., 2019; Haqshenas \& Doerig, 2019; Kawai \& Akira, 2005; Pasquale, 2010; Pike et al., 2018; Sebestyen et al., 2020; Tsukiyama et al., 2020). Receptors form dynamic assemblies, condensates, or clusters that modulate downstream signaling and thus the final physiological response. Upon activation, these receptors undergo transitions from freely diffusing monomers to less mobile nanoclusters and further to higher-order oligomers (Ojosnegros et al., 2017; Su et al., 2016). Recently, liquid-liquid phase separation (LLPS) has been considered as a general mechanism for higher-order receptor cluster formation. In these dynamic, liquid-like condensates driven by weak multivalent interactions, the likelihood of receptor activation increases as neighboring molecules can act together engaging ligands (Case et al., 2019; Lyon et al., 2021). In signal transduction, the mechanisms for receptor cluster formation and cluster behavior have become physiologically relevant topics. However, the role of mesoscale (hundreds of nanometers) receptor organization in signal transduction remains unsolved, mainly because concepts to trigger and analyze receptor clustering in situ are largely limited.

Nano- and microlithographic approaches have provided cell-compatible scaffolds to investigate confined ligand-receptor interactions (Manz \& Groves, 2010; Nair et al., 2011; Torres et al., 2008). Various techniques, ranging from photolithography to polymer lift-off and microcontact printing $(\mu \mathrm{CP})$, have yielded information on how topology and mobility of the stimulus regulate cell responses (Bernard et al., 2000; Doh \& Irvine, 2006; Mossman et al., 2005; Sánchez et al., 2018; Traub et al., 2016). So far, these methods utilize receptor ligands or antibodies to induce a rather static cluster formation. However, fast dynamic signaling at the plasma membrane requires tools that enable receptor clustering in a fast, specific, and in situ intervention of receptor networks. 
Heterotrimeric guanine nucleotide-binding protein (G protein)-coupled receptors (GPCR) are key cell surface proteins that regulate a plethora of cellular responses to external stimuli (Rosenbaum et al., 2009; Venkatakrishnan et al., 2013; Wootten et al., 2018). The $\mathrm{Y}_{2}$ receptor $\left(Y_{2} R\right)$ is one of the four human neuropeptide $Y(N P Y)$ receptor subtypes, which belong to the rhodopsin-like (class A) GPCR superfamily (Parker \& Balasubramaniam, 2008; Tang et al., 2021). $Y_{2} R$ is linked to many important physiological processes, such as fear extinction (Méndez-Couz et al., 2021), regulation of food intake (Huang et al., 2014), and obesity (Lafferty et al., 2021). ${ }_{2} R$ activation by neuropeptide $Y$ (NPY) has been shown to promote cell migration and proliferation (Ekstrand et al., 2003; Movafagh et al., 2006). Recently, we demonstrated that $Y_{2} R s$ respond to light-guided microscale clustering at spatially defined locations (Sánchez et al., 2021). ${ }_{2}$ Rs are activated independently of the presence of the canonical ligand, evoking an increase in cytosolic calcium, a change in cell spreading behavior, and a localized migratory pattern.

Here, we established a versatile concept for in situ receptor clustering using a multivalent chelator nanotool (tris $\mathrm{N}$-nitrilotriacetic acid, trisNTA), which displays high affinity for histidine (His)-tagged proteins. The small size of the chelator tool in combination with a prestructured platform enabled high-content receptor clustering with high spatiotemporal resolution. The lateral organization of $Y_{2} R s$ in living cells was controlled within minutes in a non-invasive ("traceless") and ligand-free manner. Microscale receptor condensates with a high degree of homogeneity in size and density were generated in the plasma membrane. Receptor clustering triggered ligand-independent activation of signal transduction, as evidenced by an increase in cytosolic calcium and cell motility. By evaluating arrestin-3 (Arr3) recruitment as a downstream signaling event, we uncovered high Arr3 co-recruitment to the patterned areas only in the presence of the canonical ligand, suggesting an Arr3-independent desensitization mechanism for the ligand-independent response. Strikingly, analysis of the receptor mobility revealed a dynamic receptor assembly with high exchange within the confined areas, showing similarities to liquid-like condensates. The versatility of this generic approach may advance studies of ligand-free receptor signaling by dynamic confinement. 


\section{Results}

\section{High-content receptor clustering in living cells}

We developed a system to induce dynamic receptor assembly in situ based on a multivalent chelator trisNTA nanotool (Fig 1A), which is equipped with a biotin moiety (trisNTA ${ }^{\mathrm{PEG} 12-\mathrm{B}}$ )


in a site-specific but reversible interaction (Gatterdam et al., 2018). Microcontact printing is a widely used method to investigate protein-protein interactions in living cells (Bernard et al., 2000; Torres et al., 2008). However, patterned substrates with a generic structure allowing high-content analyses of cells are difficult to produce. We used a large-area perfluoropolyether (PFPE) elastomeric stamps inked with bovine serum albumin (BSA) to print 96-well size glass (Hager et al., 2021; Lanzerstorfer et al., 2020). Wells within these plates containing a BSAstructured matrix were functionalized with biotinylated BSA (biotin-BSA) and streptavidin (SA) (Fig 1A). Subsequent functionalization with the nanotool and $\mathrm{His}_{6}$-tagged fluorescent proteins, resulted in well-resolved protein patterns that were analyzed by confocal laser scanning microscopy (CLSM). This confirmed the specificity of the nickel-loaded trisNTA chelator to capture $\mathrm{His}_{6}$-tagged proteins in defined regions of $1 \mu \mathrm{m}$ or $3 \mu \mathrm{m}$ diameter (Fig 1C, D).

The ability to control the organization of membrane receptors in real time is important for dissecting the spatial complexity of cell signaling and the extracellular environment. To this end, we utilized a tetracycline-inducible (T-Rex) expression system to establish a monoclonal human cervical cancer HeLa cell line expressing low amounts of the $Y_{2} R \quad(\sim 300,000$ receptors/cell) (Sánchez et al., 2021). $\mathrm{Y}_{2} \mathrm{Rs}$ displayed an $\mathrm{N}$-terminal $\mathrm{His}_{6}$-tag to the extracellular space and a cytosolic, C-terminal monomeric Enhanced Green Fluorescent

110 Protein (mEGFP) $\left(\mathrm{His}_{6}-\mathrm{Y}_{2} \mathrm{R}^{\mathrm{mEGFP}}\right.$, in brief $\left.\mathrm{Y}_{2} \mathrm{R}\right)$. It is worth mentioning that these modifications

111 do not affect receptor activity, selectivity, or ligand binding as demonstrated (Sánchez et al.,

112 2021). In addition, studies determined that $Y_{2} R$ does not need the $N$-terminus for ligand

113 binding (Lindner et al., 2009). $\mathrm{Y}_{2} \mathrm{R}$-positive cells properly adhered to $1 \mu \mathrm{m}$ and $3 \mu \mathrm{m} \mathrm{SA}$ 114 functionalized matrices and showed a homogeneous receptor distribution at the basal plasma 
115 membrane (Fig 1E). Addition of trisNTA ${ }^{\mathrm{PEG} 12-\mathrm{B}}(100 \mathrm{nM}$ final) triggered receptor assembly.

116 Within five minutes, all cells showed receptor patterns at the plasma membrane comparable

117 in size and density (Fig 1E, F, Fig EV1). Importantly, recruitment of soluble His ${ }_{6}$-tagged GFP

118 proteins as well as $\mathrm{Y}_{2} \mathrm{Rs}$ to $1 \mu \mathrm{m}$ prestructured spots led to analogous intensity profiles,

119 reflecting that similar densities were obtained in both cases (Fig 1D, G). In contrast, cells expressing $\mathrm{Y}_{2} \mathrm{Rs}$ lacking the $\mathrm{His}_{6}$-tag $\left(\mathrm{Y}_{2} \mathrm{R}^{\mathrm{mEGFP}}\right)$ showed no receptor clustering after addition of trisNTA ${ }^{\mathrm{PEG} 12-\mathrm{B}}$ (Fig EV2), demonstrating the specificity of the His 6 -tag/trisNTA interaction in living cells. Remarkably, ten minutes after receptor clustering by the multivalent nanotool, the $\mathrm{Y}_{2} \mathrm{R}$ enrichment resulted in an integrated receptor density equivalent to that of cells cultured on matrices functionalized with anti-His ${ }_{6}$ antibodies. However, a tenfold higher antibody concentration $(1 \mu \mathrm{M})$ was required compared to the multivalent nanotool, demonstrating its efficacy in capturing $\mathrm{His}_{6}$-tagged membrane receptors (Fig EV3). The $3 \mu \mathrm{m}$ diameter nanotool-induced receptor clusters presented a ninefold increase in integrated density compared to $1 \mu \mathrm{m}$ arrays, consistent with the increase in pattern area (Fig EV3). Overall, our approach enabled versatile in situ receptor organization with high specificity.

\section{Ligand-independent receptor clustering triggers fast signaling}

132 To follow receptor clustering in situ, $\mathrm{Y}_{2} \mathrm{R}$-expressing cells were cultured on microstructured matrices with a diameter of $1 \mu \mathrm{m}$, the smallest pattern we can produce and analyze with high accuracy. After addition of the multivalent nanotool, the receptor redistribution was tracked by confocal microscopy. Receptor clustering occurred in the first minutes and increased steadily within $10 \mathrm{~min}$, resulting in a twofold increase in receptor density compared to the initial state

137 (Fig 2A, Movie 1). Considering the average cell area of $1,420 \pm 50 \mu \mathrm{m}^{2}(\mathrm{n}=66$ cells) and the enrichment factor (twofold), we estimated a receptor density of $\sim 400$ receptors $/ \mu m^{2}$ in the patterned regions ( 300 receptors per $1 \mu \mathrm{m}$ spot), a value comparable to other receptor

140 studies utilizing Fluorescence Correlation Spectroscopy methods (Bag et al., 2015; Chen et 141 al., 2009). The kinetic profile for $Y_{2} R$ recruitment to the $1 \mu \mathrm{m}$ spots followed a pseudo-first142 order assembly rate of $0.20 \pm 0.03 \mathrm{~min}^{-1}$ (Fig 2A, C). Despite of the high affinity and kinetically 
143 stable binding $\left(k_{\text {off }}=0.18 \mathrm{~h}^{-1}\right)($ Gatterdam et al., 2018), the His-tag/trisNTA system relies on

144 molecular multivalency, which enables competition of the binding sites with histidine, thus

145 making the process of receptor assembly reversible. Addition of histidine to patterned cells led

146 to the disassembly of the receptor clusters in a rapid and complete manner, demonstrating a

147 key advantage of the approach to investigate receptor dynamics (Fig 2B).

148 Upon receptor clustering by the multivalent interaction nanotool, we observed a fast change

149 in cell spreading and motility. Analysis of cell spreading revealed a $20 \%$ increase in the total

150 cell area concomitant to receptor assembly (Fig 2A, D, Fig 3A), indicating ligand-independent

151 receptor activation upon clustering. Cells cultured on matrices in the absence of SA as well as

152 cells expressing $\mathrm{Y}_{2} \mathrm{R}^{\mathrm{mEGFP}}$ (lacking a His 6 -tag) on SA-matrices showed no significant change

153 in cell spreading upon addition of the trisNTA ${ }^{\mathrm{PEG} 12-\mathrm{B}}$ (Fig EV4). As calcium signals are widely

154 known to regulate cell motility, we monitored local calcium dynamics utilizing a far-red cellpermeable $\mathrm{Ca}^{2+}$-sensitive dye. By dual-color imaging, receptor assembly and the cytosolic calcium concentration were simultaneously recorded in living cells over the matrices. Upon

157 addition of trisNTA ${ }^{\text {PEG12-B }}$, receptor recruitment led to a twofold increase in cytosolic calcium 158 concentration with a rapid rise within two minutes (Fig 3B, C), contrary to control matrices 159 without SA (Fig EV5). This indicates that calcium signals are associated with the motility 160 change. To correlate ligand-free versus canonical receptor activation, the agonist porcine neuropeptide $Y\left(p N P Y, K_{D}=5.2 \pm 2.0 \mathrm{nM}\right.$ ) was added to pre-patterned cells. An increase in cytosolic $\mathrm{Ca}^{2+}$ was detected, which reached a plateau after one minute, followed by a slow 163 decay of the signal over a period of four minutes (Fig 3B, C). Strikingly, more receptors were 164 recruited to the patterned areas after activation via the agonist, as reflected by the increase in 165 integrated density in the patterned regions (Fig 3D). These results indicate that ligandactivated $\mathrm{Y}_{2} \mathrm{Rs}$ diffuse into areas where increased receptor density is present and preferentially localized there. Recently, specific clusters termed GPCR hot spots (40-300 nm) were visualized at the plasma membrane of living cells (Calebiro \& Jobin, 2019; Chavez-

169 Abiega et al., 2019; Hilger et al., 2018; Sungkaworn et al., 2017). These hot spots represent 170 regions where signaling preferentially occurs and where both receptors and $\mathrm{G}$ proteins are 
171 enriched. We hypothesize that the induced microscale clusters may also trigger the formation

172 of hot spots providing the ideal environment for recruitment of more active receptors and thus

173 amplification of the signal. By increasing the local effective receptor concentration, this

174 complex organization may increase both the speed and efficiency of receptor-G protein

175 coupling while enabling local signaling transduction.

176

\section{Downstream signaling by ligand-free receptor clustering}

178 We next explored the impact of receptor clustering on downstream signaling. GPCR 179 desensitization involves a complex series of events, e.g. receptor phosphorylation, arrestin180 mediated internalization, receptor recycling, and lysosomal degradation (Ziffert et al, 2020).

181 Short-term desensitization occurs within minutes and is primarily associated with arrestin preventing G protein interaction with the GPCR. Arrestins bind to activated, phosphorylated GPCRs and block receptor-G protein interaction by steric hindrance at the receptor-coupling interface, while serving as adaptors for key components of the endocytic machinery and numerous signaling proteins (Hilger et al, 2018, Wang et al, 2020). In the presence of high concentrations of the canonical ligand, an Arr3-dependent internalization, subsequent endosomal sorting, and recycling of $Y_{2} R$ to the cell membrane were observed (Walther et al., 2010; Wanka et al., 2018). However, recent studies demonstrated a strong and persistent activation of the $G_{\text {ai }}$-pathway upon $Y_{2} R$ activation, which depletes the intracellular $G$ protein repertoire before Arr3 binding can terminate signaling (Ziffert et al, 2020). To assess whether

191 ligand-free clustering leads to Arr3 recruitment, we transfected cells stably expressing the $Y_{2} R$ with Arr3 ${ }^{\text {mCherry }}$ (in brief Arr3) and monitored Arr3 recruitment in real-time by total internal reflection fluorescence (TIRF) microscopy (Fig 4A). Upon microscale receptor confinement by trisNTA ${ }^{\mathrm{PEG} 12-\mathrm{B}}$, we did not observe a significant increase in Arr3 recruitment by intensitycontrast analysis of the patterned spots, whereas a significant Arr3 recruitment was detected upon addition of the agonist pNPY (Fig 4B, C). Again, an increase in $\mathrm{Y}_{2} \mathrm{R}$ density in the

197 clustered areas was detected upon addition of pNPY (Fig 4B, D). In a subsequent step, a 
199 observed (Fig 4B, C). Interestingly, half of the intensity in the patterned regions was dissipated

200 in the presence of the pNPY, indicating that not all receptors within the cluster areas are

201 associated with the nanotool upon addition of the ligand. In addition, patterning of Arr3 was

202 also detected in cells on an anti-His ${ }_{6}$ antibody matrix within the first minutes after addition of pNPY (Fig EV6). In this case, we did not observe a significant change in receptor density upon addition of the pNPY, indicating that the high degree of immobilization and large size of the antibody might restrict the transient enrichment of active receptors into the clustered regions.

206 Overall, our results reflect a difference between Arr3 recruitment in the ligand-free mode 207 compared to ligand-activated state. These observations indirectly confirm a high-affinity 208 interaction between the $\mathrm{Y}_{2} \mathrm{R}$ and $\mathrm{Ga}_{\mathrm{i}}$ (Ziffert et al, 2020) and suggest an active recruitment of

209 G proteins that delay Arr3 recruitment and impair termination of G protein signaling.

\section{Receptor diffusion and dynamic exchange in confined regions}

212 GPCR signaling results from dynamic interactions among receptors, G proteins, and the 213 complex surrounding membrane environment, which confers flexibility and versatility on this

214 fundamental biological process. GPCR hot spots are highly heterogeneous in terms of 215 diffusion of receptors and G proteins, which rapidly switch among phases of rapid and slow 216 diffusion (Calebiro \& Jobin, 2019; Sungkaworn et al., 2017). First, we examined whether $\mathrm{Y}_{2} \mathrm{R}$ 217 clustering affects lipid diffusion and distribution by labeling the membrane with the lipid-like 218 dye CellMask. We observed a homogeneous staining of the plasma membrane, 219 demonstrating that receptor confinement does not affect membrane organization (Fig EV7).

220 To determine diffusion coefficients $(D)$, we performed fluorescence recovery after 221 photobleaching (FRAP) technique. In situ receptor clustering was triggered on $\mathrm{Y}_{2} \mathrm{R}$-expressing cells cultured on SA-matrices by addition of trisNTA ${ }^{\text {PEG12-B }}$ (100 nM, $10 \mathrm{~min}$ ). In a subsequent step, the membrane was labeled and square-shaped regions of interest (ROIs) covering four $1 \mu \mathrm{m}$-sized spots were photobleached. Fluorescence recovery was analyzed by a FRAP simulation approach that enabled calculation of diffusion coefficients independent of bleaching

226 geometry (Blumenthal et al., 2015). The diffusion coefficient of lipids obtained by FRAP 
showed an average value of $D_{\text {lipid }}=0.66 \pm 0.10 \mu \mathrm{m}^{2} / \mathrm{s}$ in agreement with literature values for free Brownian lipid diffusion at the plasma membrane (Schwille et al., 1999; Wawrezinieck et al., 2005).

To evaluate the $Y_{2} R$ mobility in the ligand-free induced clusters, we determined the receptor lateral diffusion of $\mathrm{Y}_{2} \mathrm{R}$-expressing cells cultured on SA-matrices before and after addition of $\operatorname{trisNTA}^{\text {PEG12-B }}(100 \mathrm{nM}, 10 \mathrm{~min})$. A square-shaped ROI covering four $1 \mu \mathrm{m}$-sized spots and recovery was photobleached. A significant decrease in the lateral diffusion of the $Y_{2} R$ was observed at the basal membrane of cells after receptor confinement by trisNTA ${ }^{\text {PEG12-B }}\left(D_{\text {before }}\right.$ $=0.25 \pm 0.08 \mu^{2} / \mathrm{s}$ versus $\left.D_{\text {after }}=0.10 \pm 0.03 \mu \mathrm{m}^{2} / \mathrm{s}\right)$ (Fig $\left.5 \mathrm{~A}, \mathrm{E}\right)$. Surprisingly, the receptor density showed a high recovery within $\sim 3$ min after photobleaching (Fig 5A, Fig EV8, Movie 2). Notably, no significant difference in receptor mobile fraction $\left(M_{\mathrm{f}}\right)$ before and after addition of the nanotool was observed $\left(M_{f}=0.80 \pm 0.04\right)$ (Fig 5B). Importantly, FRAP analyses of cells cultured on matrices functionalized with anti-His 6 antibodies presented a significant decrease in the receptor diffusion as well as in the $M_{\mathrm{f}}$ at the clustered spots $\left(M_{\mathrm{f}, \text { anti-His6 Ab }}=0.56 \pm 0.08\right)$ (Fig 5B, Fig EV9, Movie 3). In contrast to monovalent antibody immobilization, receptor clustering by the multivalent interaction nanotool is dynamic, allowing fast exchange of $\mathrm{His}_{6}$ tagged receptors or competition by histidine. We rationalized that free receptors can diffuse into the clustered spots and exchange with photobleached receptors at multivalent binding sites, leading to a dynamic confinement. Our results point out that a high receptor exchange is possible even in micrometer-sized clusters, an effect that likely depends on cluster size, with larger clusters showing less recovery (Sánchez et al., 2021).

Finally, we investigated the lateral receptor mobility with a higher spatiotemporal resolution using imaging fluorescence correlation spectroscopy (imFCS). FCS is used to study the diffusion of membrane proteins in living cells with single-molecule sensitivity (Fig 5C). These multiplexed FCS measurements are realized by analyzing many pixels simultaneously using a widefield setup (Harwardt et al, 2018, Kannan et al, 2006). Regions of interests (ROIs) on

$253 \quad \mathrm{Y}_{2} \mathrm{R}$-expressing cells cultured on SA-matrices were analyzed before and after addition of 254 trisNTA ${ }^{\mathrm{PEG12}-\mathrm{B}}$. Enrichment of $\mathrm{Y}_{2} \mathrm{R}$ at the basal membrane was observed with total internal 
reflection fluorescence (TIRF) microscopy (Fig 5D). Consistent with the FRAP measurements,

256 a decrease in the $Y_{2} R$ diffusion coefficient was determined upon cluster formation $\left(D_{\text {before }}=\right.$

$257 \quad 0.32 \pm 0.06 \mu \mathrm{m}^{2} / \mathrm{s}$ and $\left.D_{\text {after }}=0.16 \pm 0.05 \mu \mathrm{m}^{2} / \mathrm{s}\right)$. The receptor diffusion coefficient measured

258 before clustering is comparable to similar membrane proteins (Lippincott-Schwartz et al,

259 2001), demonstrating that the microstructured confinement does not affect the mobile fraction

260 of receptors. In contrast to FRAP, imFCS provides a two-dimensional diffusion map, which enables the determination of local differences in the lateral diffusion coefficient of membrane receptors with high precision. Quantitative analysis of the $1 \mu \mathrm{m}$ cluster spots in the acquired ROls resulted in a lateral diffusion coefficient of $D_{\text {spots }}=0.14 \pm 0.03 \mu \mathrm{m}^{2} / \mathrm{s}$ (Fig $5 \mathrm{E}$ ). Taking into consideration that imFCS detects only mobile particles, we determined a similar decrease in lateral diffusion in the patterned regions (Fig EV9) for cells cultured on matrices functionalized with anti-His ${ }_{6}$ antibodies. Taken together, we unravel that in microscale clusters, associations between $\mathrm{His}_{6}$-tagged $\mathrm{Y}_{2} \mathrm{Rs}$ and multivalent trisNTA ${ }^{\mathrm{PEG12-B}}$ resulted in decreased diffusion rate but dynamic receptor exchange with unchanged mobile fraction, which is similar to the behavior described upon ligand-activated receptor clustering. This plasticity of the confined receptors likely has a relevant impact on the efficiency of hot spot formation and GPCR signaling.

\section{Discussion}

274 We developed a versatile concept to cluster receptors in situ with minimal steric hindrance and disturbance. Ligand-independent receptor activation by confinement was unraveled by cytosolic calcium increase and changes in cell spreading and motility. Addition of the canonical

277 ligand led to a similar calcium increase and interestingly, an amplification of the signal was observed in the clustered areas concomitant with an increased receptor density. Surprisingly, we revealed a difference in triggering of downstream signaling for the ligand-free versus ligand-activated receptors as evidenced by co-recruitment of Arr3 to the clustered spots only occurring in the presence of the canonical ligand. These findings are consistent with previous results demonstrating an Arr3-dependent internalization, subsequent endosomal sorting, and 
receptor recycling to the cell membrane in the presence of high concentrations of NPY

284 (Walther et al., 2010; Wanka et al., 2018). We hypothesize that high-affinity $\mathrm{Y}_{2} \mathrm{R} / \mathrm{Ga}_{\mathrm{i}}$ interactions drive the initial cell response, cytosolic calcium increase, and cell motility. High local receptor density in the spots increases the residence time of proximate $\mathrm{Ga}_{\mathrm{i}}$ proteins and recruits further downstream effectors, which boost the probability of activation (Sánchez et al., 2021). Further, $Y_{2} R / G \alpha_{i}$ interactions lead to persistent activation of the $G \alpha_{i}$ pathway, which depletes the intracellular $\mathrm{Ga}_{\mathrm{i}}$ protein repertoire before Arr3 binding can terminate signaling (Ziffert et al., 2020). The time frame of imaging after addition of the nanotool (30 min) suggests a long-lasting $\mathrm{Ga}_{i}$ protein activation and favors the hypothesis of a mechanism for $Y_{2} R$ activation and desensitization that is limited to the cell membrane and partially independent of Arr3 recruitment (Ziffert et al., 2020).

Many transmembrane receptors form dynamic assemblies that promote downstream signal transduction in cells. Recently, dynamic liquid-like microscale clusters were identified as critical modulators of cell signaling (Case et al., 2019; Lyon et al., 2021). In our system, the transient association between the nanotool and the receptors revealed the generation of a dynamic platform for cell signaling, which may have characteristics akin liquid-like clusters generated by LLPS. The dynamic exchange of molecules within induced $Y_{2} R$ microscale clusters may contribute to hot spots formation and final downstream signaling. This characteristic together with the lower concentration required compared to established systems with immobilized ligands or antibodies, highlight the relevance of this versatile approach along with the developed nanotool. Multiscale analyses of the multivalent interactions between receptor condensates, G proteins, the lipid environment and actin-myosin assemblies are critical to confirm the cluster behavior and dynamics. In vitro reconstitution systems utilizing lipid bilayers have proven phase-segregation in two dimensions (Banjade \& Rosen, 2014;

307 Ditlev et al., 2019). The comparison of a mobile system based on model membranes and our 308 established platform, together with advanced quantitative fluorescence microscopy 309 techniques such as fluorescence resonance energy transfer (FRET) and single-molecule 310 localization microscopy will help us to decode condensates behavior and ligand-independent 
bioRxiv preprint doi: https://doi.org/10.1101/2021.12.15.472742; this version posted December $17,2021$. The copyright holder for this

preprint (which was not certified by peer review) is the author/funder, who has granted bioRxiv a license to display the preprint in perpetuity. It is made available under aCC-BY-NC-ND 4.0 International license.

311 signaling. In summary, the developed tool and matrices allow the investigation of ligand-

312 independent receptor activation in situ facilitating the investigation of early key processes in

313 cell signaling. 


\section{Materials and Methods}

315 Synthesis of trisNTA ${ }^{\text {PEG12-B }}$ : Cyclam-Lys-trisNTA (Gatterdam et al., 2018) (5.0 mg, $\left.4.8 \mu \mathrm{mol}\right)$,

316 Biotin-PEG ${ }_{12}-\mathrm{NHS}(23.0 \mathrm{mg}, 24.0 \mu \mathrm{mol})$ and DIPEA $(12.2 \mu \mathrm{L}, 72.0 \mu \mathrm{mol})$ were dissolved in

$3170.5 \mathrm{ml}$ dry DMF and stirred for $2 \mathrm{~h}$ at RT. After reaction, the volatile components were removed

318 by lyophilization. Raw product was purified by semi-preparative RP-HPLC (mobile phase A:

$319 \mathrm{H}_{2} \mathrm{O}+0.1 \%$ TFA, B: CAN $+0.1 \%$ TFA; gradient $5 \%$ to $80 \%$ B in 20 min; MZ-PerfectSil, 300

320 ODS, $5 \mu \mathrm{m}, 250 \times 10 \mathrm{~mm}$, flow $4 \mathrm{ml} / \mathrm{min}$ ). A biotin moiety was integrated into the nanotool for

321 immobilization to $S A$ in the prestructured matrices. The $P E G_{12}$ linker between the biotin and

322 the trisNTA unit increased the flexibility of the molecule. trisNTA ${ }^{\mathrm{PEG} 12-\mathrm{B}}$ was confirmed by liquid

323 chromatography-mass spectrometry (LC-MS, Waters BioAccord System). Dataset was

324 recorded with an ACQUITY UPLC I-Class Plus chromatography system and ACQUITY RDa

325 Detector, which was set to a cone voltage of $25 \mathrm{~V}$, capillary voltage of $1.2 \mathrm{kV}$ and a desolvation

326 temperature of $500{ }^{\circ} \mathrm{C}$ operating in positive ionization mode. For reverse-phase separation,

327 an ACQUITY UPLC Peptide BEH C18 column (300 A, $1.7 \mu \mathrm{m}, 2.1 \mathrm{~mm}$ x $100 \mathrm{~mm}$ ) was used

328 (Fig EV10). The trisNTA chelator compounds were dissolved in HBS buffer (20 mM HEPES-

$329 \mathrm{NaOH} \mathrm{pH} 7.5,150 \mathrm{mM} \mathrm{NaCl}$ ) and incubated with tenfold excess of $\mathrm{NiCl}_{2}$. After 30 min

330 incubation at $4{ }^{\circ} \mathrm{C}$, the excess of $\mathrm{Ni}(\mathrm{II})$ was separated by ultra-centrifugal filters (Amicon Ultra-

$331 \quad 0.5 \mathrm{ml} ; 3 \mathrm{kDa}$ and $10 \mathrm{kDa} \mathrm{MWCO})$.

333 Microcontact printing. Large-area microcontact printing was performed as described

334 previously (Lanzerstorfer et al., 2020) with modifications. In short, a field of a large-area PFPE elastomeric stamp ( $1 \mu \mathrm{m}$ grid size), obtained by the EV-Group (St. Florian am Inn, Upper

336 Austria, Austria), was cut out, and washed by flushing with ethanol (100\%) and distilled water.

337 After drying with nitrogen, the stamp was incubated in $50 \mathrm{ml} \mathrm{BSA}$ solution $(1 \mathrm{mg} / \mathrm{ml}$, Sigma-

338 Aldrich) for 30 min followed by washing the stamp with phosphate-buffered saline (PBS) and

339 distilled water. After drying with nitrogen, the stamp was placed with homogeneous pressure

340 onto a clean epoxy-coated glass substrate (Schott Nexterion Slide E) and incubated overnight 
at $4{ }^{\circ} \mathrm{C}$. The next day, the stamp was stripped from the glass with a forceps, and the microstructured glass was bonded to a 96-well plastic casting using an adhesive tape (3M) and closed with an appropriate lid.

Functionalization of the prestructured matrices. BSA-prestructured wells were incubated with biotin-BSA $(0.1 \mathrm{mg} / \mathrm{ml}$, Thermo Fisher Scientific) and SA (1 $\mu \mathrm{M}$, Sigma-Aldrich) in PBS, each for $1 \mathrm{~h}$ at RT. Incubated wells were washed thoroughly with PBS after each step, to remove unbound biotin-BSA and SA. For binding of soluble His-tagged proteins, wells were incubated with trisNTA ${ }^{\mathrm{PEG} 12-\mathrm{B}}(0.5 \mu \mathrm{M})$ in HBS buffer for $1 \mathrm{~h}$ at $\mathrm{RT}$. For nickel-loading, the prestructured matrices were sequentially incubated with imidazole (1 $\mathrm{M}, 2 \mathrm{~min}$ ), EDTA (100 mM, $2 \mathrm{~min}$ ), and $\mathrm{NiCl}_{2}(10 \mathrm{mM}, 5 \mathrm{~min})$. Wells were carefully washed after each step. Finally, HBS buffer containing EDTA $(50 \mu \mathrm{M})$ was used to remove the free, non-complexed nickel ions. His ${ }_{6}$-GFP (100 nM) previously expressed and purified was added to the wells and incubated for $30 \mathrm{~min}$ at RT. Experiments were performed in biological replicas $(\mathrm{N}=5)$.

Cell culture. HeLa Flp-In ${ }^{T M}$ T-Rex ${ }^{T M} Y_{2} R$ cells $\left(H_{i s_{6}-} Y_{2} R^{\text {mEGFP }}\right.$ or $\left.Y_{2} R^{\text {mEGFP }}\right)$ were generated as previously described (Sánchez et al., 2021) and cultured at $37{ }^{\circ} \mathrm{C}, 5 \% \mathrm{CO}_{2}$, and $95 \%$ humidity.

358 For culturing the stable cell line, high glucose Dulbecco's modified Eagle's medium (DMEM)

359 (Gibco/Thermo Fisher Scientific) was supplemented with $10 \%$ tetracycline-free fetal calf 360 serum (FCS, Bio\&Sell), blasticidin S $\mathrm{HCl}(1 \mu \mathrm{g} / \mathrm{ml}$, Thermo Fisher Scientific) and hygromycin B (50 $\mu \mathrm{g} / \mathrm{ml}$, Thermo Fisher Scientific). To induce receptor expression, the cell medium was replaced with fresh medium containing tetracycline $(0.1 \mu \mathrm{g} / \mathrm{ml}$, Fluka) $18 \mathrm{~h}$ before imaging. The same concentration of tetracycline resulting in an efficient plasma membrane targeting was used for all the experiments. The cells were regularly tested for mycoplasma contamination. 
367 Receptor confinement in real-time by trisNTA ${ }^{\text {PEG12-B }}$. Cells expressing $Y_{2} R\left(H_{i S_{6}-Y_{2} R^{m E G F P}}\right.$

368 or $\mathrm{Y}_{2} \mathrm{R}^{\mathrm{mEGFP}}$ ) were trypsinized and allowed to adhere to $\mathrm{SA}$ prestructured matrices for $3 \mathrm{~h}$ or 369 overnight. 15-18 $\mathrm{h}$ prior to the experiment, the cell medium was replaced with fresh medium 370 containing tetracycline $(0.1 \mu \mathrm{g} / \mathrm{ml})$ to induce receptor expression. The cells were visualized by 371 CLSM in live-cell imaging solution (LCIS, Thermo Fisher Scientific) at $37^{\circ} \mathrm{C}$. Cells were 372 subsequently incubated with nickel-loaded trisNTA ${ }^{\text {PEG12-B }}(100 \mathrm{nM})$ in LCIS for 10-15 min at $37^{\circ} \mathrm{C}$. Excess of unbound trisNTA ${ }^{\mathrm{PEG} 12-\mathrm{B}}$ was removed by washing with LCIS. For reversibility experiments, micropatterned cells were incubated with histidine ( $5 \mathrm{mM})$ in LCIS for 2 to $10 \mathrm{~min}$ followed by washing with LCIS. Experiments were performed in biological replicas $(\mathrm{N}=4)$.

Receptor confinement on antibody-micropatterned matrices. Wells prestructured with BSA were subsequently incubated with biotin-BSA $(0.1 \mathrm{mg} / \mathrm{ml}), \mathrm{SA}(1 \mu \mathrm{M})$, and a biotinylated anti-His $_{6}$ antibody $(1 \mu \mathrm{M})(\mathrm{ab} 106261, \mathrm{Abcam})$ in PBS for $1 \mathrm{~h}$ at RT. Wells were washed thoroughly with PBS to remove unbound antibody. Cells expressing $Y_{2} R$ were trypsinized and seeded onto the antibody patterns. After $3 \mathrm{~h}$, cells were visualized by CLSM in LCIS at $37^{\circ} \mathrm{C}$. Experiments were performed in biological replicas $(\mathrm{N}=5)$.

Time-lapse calcium imaging. $18 \mathrm{~h}$ after seeding the cells onto prestructured SA-matrices, cells were incubated with BioTracker $609 \mathrm{Red} \mathrm{Ca}^{2+} \mathrm{AM}$ dye $(3 \mu \mathrm{M}$, Merck Millipore) in fresh medium for $30 \mathrm{~min}$. The cell-membrane permeable dye is de-esterified by cellular esterases and remains trapped in the cytosol. After incubation with the $\mathrm{Ca}^{2+}$ dye, cells were rinsed three times with PBS and imaged by CLSM in LCIS at $37^{\circ} \mathrm{C}$. For investigation of $\mathrm{Ca}^{2+}$ signal, timelapse images were taken ( 5 slices z-stacks, 45 -s interval) before and after addition of trisNTA $^{\text {PEG12-B }}$. Fluorescence intensity $\left(\left(\lambda_{\text {ex/em }} 590 / 609 \mathrm{~nm}\right)\right.$ of the dye changes depending on the intracellular $\mathrm{Ca}^{2+}$ concentration. Maximum intensity projections of single channels were analyzed. The ImageJ ROI tool was used to define the areas of the image to be analyzed. We consider a ROI covering the complete cell contour. Mean gray value (F) were background 
394 subtracted and normalized to the fluorescence in cells before $F_{0}$. Experiments were performed

395 in biological replicas $(\mathrm{N}=3)$.

397 Plasma membrane staining. Live-cell membrane staining was performed directly after receptor assembly in living cells grown on prestructured matrices. CellMask ${ }^{\mathrm{TM}}$ deep red plasma membrane stain (Thermo Fisher Scientific) was used according to manufacturer's instruction. $1 \mu \mathrm{l}$ of the stock solution (1000x dilution) was dissolved in $1 \mathrm{ml}$ of warm LCIS (final concentration $5 \mu \mathrm{g} / \mathrm{ml}$ ) and subsequently added to the cells, incubated for $5 \mathrm{~min}$ at $37^{\circ} \mathrm{C}$, and washed with LCIS before visualization. Experiments were performed in biological replicas $(\mathrm{N}=3)$.

Confocal laser scanning microscopy. Images were recorded by using a CLSM Zeiss LSM 880 (Carl Zeiss) equipped with a Plan-Apochromat 63x/1.4 Oil DIC M-27 objective. Sequential settings for dual-color imaging were used. Excitation wavelengths for the different fluorophores: $488 \mathrm{~nm}$ (argon laser) for mEGFP; $594 \mathrm{~nm}$ for the $\mathrm{Ca}^{2+}$ dye; $633 \mathrm{~nm}$ (heliumneon laser) for the plasma membrane dye. Signals were detected after appropriate filtering on a photomultiplier. Intensities of channels were adjusted over the whole image for better

411 visualization of overlap and exported by Zen blue (version 2.3 lite, Zeiss). Detector amplification, laser power, and pinhole were kept constant for all studies.

414 Image analysis. Fluorescence images were processed with Zen blue, ImageJ, and Fiji 415 software (Schindelin et al., 2012; Schneider et al., 2012). All images were background 416 subtracted. Integrated density, mean gray value and cell area were obtained with ImageJ. 417 Graphs were plotted with OriginPro. 
419 Fluorescence recovery after photobleaching. FRAP experiments were conducted at the

420 CLSM Zeiss LSM 880 using 63 x/1.4 Oil DIC objective. Rectangular-shaped regions (6-10 $\mu \mathrm{m}$

421 radius) were bleached within $10 \mathrm{~s}$ with high laser intensities. Fluorescence recovery was

422 monitored by repetitively imaging an area containing the photobleached region at 0.1 frame/s

423 for $\sim 150 \mathrm{~s}$. For the analysis, a simulation approach that allows computation of diffusion

424 coefficients regardless of bleaching geometry used in the FRAP series was applied

425 (Blumenthal et al., 2015). The method is based on fitting a computer-simulated recovery to

426 actual recovery data of a FRAP series. The algorithm accepts a multiple-frame TIFF file,

427 representing the experiment as input, and simulates the (pure) diffusion of the fluorescent

428 probes ( $2 D$ random walk) starting with the first post-bleach frame of the actual data. Once the

429 simulated recovery is finished, the algorithm fits the simulated data to the real one and extracts

430 the diffusion coefficient. The algorithm iteratively creates a series of simulated images, where

431 each frame corresponds to a single iteration. The intensity values are extracted from the (user

432 indicated) bleached area of the simulated frames, thus determining the general shape of the

433 recovery curve. The "time" axis at this stage is in arbitrary units (iterations). To extract the

434 diffusion coefficient, the simulated recovery curve needs to be fitted to the real recovery curve,

435 by appropriately stretching the "time" axis. The time between frames in the actual data set is

436 obviously known, thus once overlapping optimally the simulated curve with the real one, the

437 duration of one iteration, in real-time units, is determined. The diffusion coefficient of the

438 simulated series is then calculated according to eq. 1 ,

439 where $D_{S}$ is the simulation-extracted diffusion coefficient, $l$ is the step of a molecule in each

$$
D_{s}=\frac{l^{2}}{4 t_{i}}
$$

440 iteration of the simulation, corresponding to one pixel in the image (the pixel size is calibrated 441 previously, by imaging a known calibration sample), and $t_{i}$ is the time interval between steps 442 (determined as explained). Technically, the simulation proceeds until a plateau is reached 443 (equilibration of the fluorescence intensity in the bleached area). The number of data points in 444 the simulated recovery is typically different (larger) than the number of experimental points. In 
addition, the real experimental data may not have been acquired until equilibration of

446 fluorescence. To determine $t_{i}$, the algorithm scans a range of possible values for the total

447 duration represented by the simulation and calculates a value $X^{2}$ for the goodness-of-fit

448 between the simulated data and the real FRAP data. Total simulation duration is selected as

449 the one that produces the minimal $X^{2}$. Experiments were performed in biological replicas

$450 \quad(\mathrm{~N}=3)$.

imFCS measurements. imFCS measurements were performed as described earlier

453 (Harwardt et al., 2018; Harwardt et al., 2017). A home-built widefield setup with total internal

reflection fluorescence (TIRF) illumination was used for imFCS analysis. The experimental setup was equipped with a $488 \mathrm{~nm}$ diode laser (100 mW, Obis, Coherent, USA). The excitation light passes through an acousto-optical tunable filter (AA Opto-Electronic, Orsay, France) and a telescope consisting of two achromatic lenses (Thorlabs, USA) with $f=-40 \mathrm{~mm}$ and $750 \mathrm{~mm}$. A third achromatic lens $(f=400 \mathrm{~mm}$, Thorlabs) directed the excitation light to the TIRF mirror and had its focus on the back focal plane of the objective. The TIRF mirror was placed on a motorized translation stage (25 mm, \#MTS25/M-Z8, Thorlabs) controlled by a motion controller (K-Cube Brushed DC Servo Motor Controller, \# KDC101, Thorlabs) to switch between widefield and TIRF illumination. The light entered an Eclipse Ti microscope (Nikon, Japan), was reflected by a dichroic mirror (TIRF-Quad filter set 405/488/561/640 consisting of a QuadLine Laser Clean-up ZET405/488/561/640x, QuadLine dichroic zt405/488/561/640rpc, QuadLine rejection band ZET405/488/561/640 TIRF, all AHF Analysentechnik AG, Tübingen, Germany), and was directed by an oil-immersion TIRF objective (UapoN 100xOTIRF, 1.49

467 Oil, Olympus, Japan) onto the sample. A nosepiece stage (IX2-NPS, Olympus) was used for z plane adjustment and drift minimization. Emission light was collected by the same objective and passed the dichroic mirror. In the detection path a TwinCam (Acal Bfi, Germany) with a BrightLine HC 525/45 bandpass filter (AHF Analysentechnik AG) was implemented and the signal was detected by a scientific complementary metal-oxide semiconductor (sCMOS) 
$473 \mu$ Manager (Edelstein et al., 2010). For data acquisition the following settings were applied:

$47424 \mathrm{~W} / \mathrm{cm}^{2}$ laser intensity, a bit depth of 16 bit, pixel readout rate of $540 \mathrm{MHz}$, frame time $4 \mathrm{ms,}$ $4 \times 4$ binning, and 4,000 frames per film. For each film, a 40x25 pixel (or 40x20 pixel) region of interest (ROI) was chosen and the measurement was performed with TIRF illumination to observe membrane diffusion of $Y_{2} R$. In total 36 untreated cells, 24 cells with trisNTA ${ }^{\text {PEG12-B }}$ immobilized receptors, and 26 cells with anti-His 6 antibody immobilized receptors were measured. Each condition contains data from at least three independent measurement days $480 \quad(N=3)$.

imFCS data analysis. Analysis of imFCS films was performed using the imFCS plugin (version 1.52) (Sankaran et al., 2010) for Fiji (Schindelin et al., 2012). The following correlation settings were chosen: emission wavelength $=515 \mathrm{~nm}, \mathrm{NA}=1.49$, correlator scheme $\mathrm{P}=16$ and $\mathrm{Q}=8$, lateral $\mathrm{PSF}=0.8$, binning $=1$, pixel size $=5.75 \mu \mathrm{m}$, magnification $=25$ for $4 \times 4$ binning, and linear segment bleach correction with linear segments of 500 frames. Diffusion coefficients were obtained for each pixel by fitting the correlation curves according to the literature (Sankaran et al., 2010). To compare the overall diffusion coefficients with those of the patterned regions, ROls were placed around patterned regions and analyzed separately. For further analysis, the pixelwise diffusion coefficients for all measurements were imported into OriginPro 2019 (OriginLab Corporation, Northampton, USA). For box plots of diffusion coefficients, median diffusion coefficients were determined for each cell. Mean diffusion coefficients per condition were obtained by averaging over the median diffusion coefficients per measurement and calculating the standard error of the mean. Two-sample t-tests $(\alpha=$ 0.05) were applied to compare the diffusion coefficients for the different conditions. All datasets were tested for normality using the Kolmogorov-Smirnov test $(\alpha=0.05)$. Significance was assigned as follows: $p>0.05$ no significant difference between populations (n.s.), $p<$ 0.05 significant difference $\left({ }^{*}\right), p<0.01$ significant difference $\left({ }^{* *}\right)$, and $p<0.001$ significant difference $\left.{ }^{(* *}\right)$. Two-dimensional maps of diffusion coefficients were generated also in 
5010 to $0.5 \mu \mathrm{m}^{2} / \mathrm{s}$. Pixels that yielded correlation curves with diffusion coefficients higher than

$5020.5 \mu \mathrm{m}^{2} / \mathrm{s}$ are presented in black. Pixels that yielded correlation curves which could not be

503 fitted by the imFCS plugin in Fiji are shown in light grey. To generate frequency distribution

504 plots, diffusion coefficients were log-transformed and binned in the interval between -5.3 and 1.0 with a bin size of 0.1 for each cell. Logarithmic diffusion coefficients were re-transformed, frequency counts were averaged over all cells per condition and normalized. Frequency counts were plotted logarithmically against diffusion coefficients. Errors bars represent standard errors of the mean.

Arr3 recruitment upon receptor confinement. Microstructured surfaces were functionalized

511 with biotin-BSA and SA or SA and anti-His 6 antibody as described before. For transient cotransfection with Arr $3^{\text {mCherry }}$, cells were sub-cultured the day before and then transfected with the Arr $3^{\text {mCherry }}$ plasmid using the TurboFect ${ }^{\mathrm{TM}}$ transfection reagent (Thermo Fisher Scientific,

514 Waltham, MA, USA), according to the manufacturer's instructions and induced with

515 Tetracycline $(0.1 \mu \mathrm{g} / \mathrm{ml}) 18 \mathrm{~h}$ before microscopy. Cells co-expressing $\mathrm{His}_{6}-\mathrm{Y}_{2} \mathrm{R}^{\mathrm{mGFP}}$ and Arr3

516 were seeded onto the microstructured matrices and visualized by total internal reflection

517 fluorescence (TIRF) microscopy in LCIS at $37^{\circ} \mathrm{C}$ after 3 to $4 \mathrm{~h}$ to ensure a homogeneous cell

518 membrane adhesion, which is a prerequisite for quantitative TIRF microscopy. For antibody experiments, cells grown on prestructured matrices were incubated with pNPY (10 nM, Tocris) in LCIS for 30 min at $37^{\circ} \mathrm{C}$. For trisNTA ${ }^{\mathrm{PEG} 12-\mathrm{B}}$ experiments, cells grown on SA-matrices were subsequently incubated with nickel-loaded trisNTA ${ }^{\text {PEG12-B }}(100 \mathrm{nM})$ and pNPY $(10 \mathrm{nM})$ in LCIS for $30 \mathrm{~min}$ at $37^{\circ} \mathrm{C}$. For reversibility, cells were incubated with histidine $(5 \mathrm{mM})$ in LCIS for 30 min. Experiments were performed in biological replicas $(\mathrm{N}=2)$.

Arr3 imaging by TIRF microscopy. The detection system was set up on an epi-fluorescence microscope (Nikon Eclipse Ti2). For selective fluorescence excitation of mGFP and mCherry,

527 a multi-laser engine (Toptica Photonics, Munich, Germany) was used at 488 and $561 \mathrm{~nm}$, 528 respectively. The samples were illuminated in total internal reflection (TIR) configuration 
529 (Nikon Ti-LAPP) using a 60x oil immersion objective (NA = 1.49, APON 60XO TIRF). After

530 appropriate filtering using standard filter sets, the fluorescence was imaged onto a sCMOS

531 camera (Zyla 4.2, Andor, Northern Ireland). The samples were mounted on an $x$-y-stage

532 (CMR-STG-MHIX2-motorized table, Märzhäuser, Germany), and scanning was supported by

533 a laser-guided automated Perfect Focus System (Nikon PFS).

535 Contrast Quantification and Statistical Analysis. Contrast analysis was performed as 536 described previously (Lanzerstorfer et al., 2014; Lanzerstorfer et al., 2020; Schütz et al., 537 2017). Initial imaging recording was supported by the Nikon NIS Elements software. Images 538 were exported as TIFF frames and fluorescence contrast analysis was performed using the 539 Spotty framework (Borgmann et al., 2012). The fluorescence contrast $\langle c\rangle$ was calculated as $540<\mathrm{c}>=\left(\mathrm{F}^{+}-\mathrm{F}^{-}\right) /\left(\mathrm{F}^{+}-\mathrm{F}_{\mathrm{bg}}\right)$, where $\mathrm{F}^{+}$denotes the intensity of the inner pixels of the pattern. $\mathrm{F}^{-}$ 541 shows the intensity of the surrounding pixels of the micropattern, and $F_{b g}$ the intensity of the

542 global background. Data are expressed as the means \pm SEM. Comparisons of more than two 543 different groups were performed using one-way ANOVA, which was followed by Tukey's 544 multiple comparisons test in GraphPad Prism software (version 9.1.2). 


\section{Acknowledgements}

546 We thank Christian Winter, Andrea Pott, Inga Nold, and all members of the Institute of

547 Biochemistry (Goethe University Frankfurt) for discussion and comments. We thank Dr.

548 Annette Beck-Sickinger (Leipzig University) for the $\mathrm{Y}_{2}$ receptor construct and Dr. Alina Klein

549 (Goethe University Frankfurt) for the generation of the $\mathrm{Y}_{2} \mathrm{R}^{\mathrm{mEGFP}}$ constructs with and without

550 His 6 -tag. We tank Dr. Cornelius Krasel (Philipps University of Marburg) for the Arr3 ${ }^{\text {mCherry }}$

551 construct. We also thank Christian Winter for the LC-MS analysis. This work was supported

552 by the German Research Foundation (GRK 1986 (No. 237922874) to R.W. and R.T.; CRC

553807 (No. 57566863) P16 to R.T.), LOEWE DynaMem P3 to R.W. and R.T., the Volkswagen

554 Foundation (Az. 96498 to R.W., Az. 96497 to M.H., and Az. 96496 to R.T.); the Christian-

555 Doppler Forschungsgesellschaft (Josef Ressel Centre for Phytogenic Drug Research, the

556 Austrian Science Fund (FWF, 14972-B) and the FH Upper Austria Center of Excellence for

557 Technological Innovation in Medicine (TIMed Center) to U.M., J.W. and P.L..

558

559 Author contributions

560 M.F.S. performed the cell-based assays and imaging experiments. M.S.D. carried out the

561 imFCS experiments and analyzed the data together with M.H.. U.M., P.L., and J.W. prepared

562 the prestructured surfaces, performed the Arr3 recruitment assays and the intensity-contrast

563 analysis. K.G. synthesized and characterized the chelator compound. M.F.S., R.W., and R.T.

564 wrote the manuscript with contributions from all authors. R.T. conceived the study.

566 Competing interest. The authors declare no competing interest.

568 Data availability. Data and movies are available in the supplementary materials. 


\section{References}

Bag N, Huang S, Wohland T (2015) Plasma Membrane Organization of Epidermal Growth Factor Receptor in Resting and Ligand-Bound States. Biophys J 109: 1925-36.

Banjade S, Rosen MK (2014) Phase transitions of multivalent proteins can promote clustering of membrane receptors. Elife 3

Bernard A, Renault JP, Michel B, Bosshard HR, Delamarche E (2000) Microcontact printing of proteins. Advanced Materials 12: 1067-70.

Blumenthal D, Goldstien L, Edidin M, Gheber LA (2015) Universal Approach to FRAP Analysis of Arbitrary Bleaching Patterns. Sci Rep 5: 11655.

Boncompain G, Herit F, Tessier S, Lescure A, Del Nery E, Gestraud P, Staropoli I, Fukata Y, Fukata M, Brelot A, Niedergang F, Perez F (2019) Targeting CCR5 trafficking to inhibit HIV-1 infection. Sci Adv 5: eaax0821.

Borgmann D, Weghuber J, Schaller S, Jacak J, Winkler SM (2012) Identification of patterns in microscopy images of biological samples using evolution strategies. In Proceedings of the 24th European Modeling and Simulation Symposium.

Calebiro D, Jobin ML (2019) Hot spots for GPCR signaling: lessons from single-molecule microscopy. Curr Opin Cell Biol 57: 57-63.

Case LB, Ditlev JA, Rosen MK (2019) Regulation of Transmembrane Signaling by Phase Separation. Annu Rev Biophys 48: 465-94.

Chavez-Abiega S, Goedhart J, Bruggeman FJ (2019) Physical biology of GPCR signalling dynamics inferred from fluorescence spectroscopy and imaging. Curr Opin Struct Biol 55: 204-11.

Chen Y, Munteanu AC, Huang YF, Phillips J, Zhu Z, Mavros M, Tan W (2009) Mapping receptor density on live cells by using fluorescence correlation spectroscopy. Chemistry 15: $5327-36$.

Ditlev JA, Vega AR, Koster DV, Su X, Tani T, Lakoduk AM, Vale RD, Mayor S, Jaqaman K, Rosen MK (2019) A composition-dependent molecular clutch between T cell signaling condensates and actin. Elife 8

Doh J, Irvine DJ (2006) Immunological synapse arrays: patterned protein surfaces that modulate immunological synapse structure formation in T cells. Proc Natl Acad Sci U S A 103: 5700-5.

Edelstein A, Amodaj N, Hoover K, Vale R, Stuurman N (2010) Computer control of microscopes using $\mu$ Manager. Curr Protoc Mol Biol Chapter 14: Unit14.20.

Ekstrand AJ, Cao R, Bjorndahl M, Nystrom S, Jonsson-Rylander AC, Hassani H, Hallberg B, Nordlander M, Cao Y (2003) Deletion of neuropeptide Y (NPY) 2 receptor in mice results in blockage of NPY-induced angiogenesis and delayed wound healing. Proc Natl Acad Sci U S A 100: 6033-8. 
606

607

608

609

610

611

612

613

614

615

616

617

618

619

620

621

622

623

624

625

626

627

628

629

630

631

632

633

634

635

636

637

638

639

640

641

642

Gatterdam K, Joest EF, Gatterdam V, Tampe R (2018) The scaffold design of trivalent chelator heads dictates affinity and stability for labeling His-tagged proteins in vitro and in cells. Angew Chem Int Ed Engl 57: 12395-9.

Hager R, Müller U, Ollinger N, Weghuber J, Lanzerstorfer P (2021) Subcellular Dynamic Immunopatterning of Cytosolic Protein Complexes on Microstructured Polymer Substrates. ACS Sens

Haqshenas G, Doerig C (2019) Targeting of host cell receptor tyrosine kinases by intracellular pathogens. Sci Signal 12

Harwardt MIE, Dietz MS, Heilemann M, Wohland T (2018) SPT and Imaging FCS Provide Complementary Information on the Dynamics of Plasma Membrane Molecules. Biophys J 114: 2432-43.

Harwardt MIE, Young P, Bleymüller WM, Meyer T, Karathanasis C, Niemann HH, Heilemann M, Dietz MS (2017) Membrane dynamics of resting and internalin B-bound MET receptor tyrosine kinase studied by single-molecule tracking. FEBS Open Bio 7: 142240.

Hilger D, Masureel M, Kobilka BK (2018) Structure and dynamics of GPCR signaling complexes. Nat Struct Mol Biol 25: 4-12.

Huang L, Tan HY, Fogarty MJ, Andrews ZB, Veldhuis JD, Herzog H, Steyn FJ, Chen C (2014) Actions of NPY, and its $Y 1$ and $Y 2$ receptors on pulsatile growth hormone secretion during the fed and fasted state. J Neurosci 34: 16309-19.

Kawai T, Akira S (2005) Pathogen recognition with Toll-like receptors. Curr Opin Immunol 17: 338-44.

Kupperman E, An S, Osborne N, Waldron S, Stainier DY (2000) A sphingosine-1-phosphate receptor regulates cell migration during vertebrate heart development. Nature 406: $192-$ 5.

Lafferty RA, Flatt PR, Irwin N (2021) Established and emerging roles peptide YY (PYY) and exploitation in obesity-diabetes. Curr Opin Endocrinol Diabetes Obes 28: 253-61.

Lanzerstorfer P, Borgmann D, Schütz G, Winkler SM, Höglinger O, Weghuber J (2014)

Quantification and kinetic analysis of Grb2-EGFR interaction on micro-patterned surfaces for the characterization of EGFR-modulating substances. PLoS One 9: e92151.

Lanzerstorfer P, Müller U, Gordiyenko K, Weghuber J, Niemeyer CM (2020) Highly Modular Protein Micropatterning Sheds Light on the Role of Clathrin-Mediated Endocytosis for the Quantitative Analysis of Protein-Protein Interactions in Live Cells. Biomolecules 10: 540.

Li MO, Rudensky AY (2016) T cell receptor signalling in the control of regulatory T cell differentiation and function. Nat Rev Immunol 16: 220-33. 
Lindner D, Walther C, Tennemann A, Beck-Sickinger AG (2009) Functional role of the extracellular $\mathrm{N}$-terminal domain of neuropeptide $\mathrm{Y}$ subfamily receptors in membrane integration and agonist-stimulated internalization. Cell Signal 21: 61-8.

Luther SA, Cyster JG (2001) Chemokines as regulators of T cell differentiation. Nat Immunol 2: $102-7$.

Lyon AS, Peeples WB, Rosen MK (2021) A framework for understanding the functions of biomolecular condensates across scales. Nat Rev Mol Cell Biol 22: 215-35.

Manz BN, Groves JT (2010) Spatial organization and signal transduction at intercellular junctions. Nat Rev Mol Cell Biol 11: 342-52.

Méndez-Couz M, Manahan-Vaughan D, Silva AP, González-Pardo H, Arias JL, Conejo NM (2021) Metaplastic contribution of neuropeptide $Y$ receptors to spatial memory acquisition. Behav Brain Res 396: 112864.

Mossman KD, Campi G, Groves JT, Dustin ML (2005) Altered TCR signaling from geometrically repatterned immunological synapses. Science 310: 1191-3.

Movafagh S, Hobson JP, Spiegel S, Kleinman HK, Zukowska Z (2006) Neuropeptide Y induces migration, proliferation, and tube formation of endothelial cells bimodally via $Y 1$, Y2, and Y5 receptors. Faseb j 20: 1924-6.

Nair PM, Salaita K, Petit RS, Groves JT (2011) Using patterned supported lipid membranes to investigate the role of receptor organization in intercellular signaling. Nat Protoc 6: 523-39.

Ojosnegros S, Cutrale F, Rodríguez D, Otterstrom JJ, Chiu CL, Hortigüela V, Tarantino C, Seriola A, Mieruszynski S, Martínez E, Lakadamyali M, Raya A, Fraser SE (2017) Ephephrin signaling modulated by polymerization and condensation of receptors. Proc Natl Acad Sci U S A 114: 13188-93.

Parker SL, Balasubramaniam A (2008) Neuropeptide Y Y2 receptor in health and disease. Br J Pharmacol 153: 420-31.

Pasquale EB (2010) Eph receptors and ephrins in cancer: bidirectional signalling and beyond. Nat Rev Cancer 10: 165-80.

Pike R, Ortiz-Zapater E, Lumicisi B, Santis G, Parsons M (2018) KIF22 coordinates CAR and EGFR dynamics to promote cancer cell proliferation. Sci Signal 11

Rosenbaum DM, Rasmussen SG, Kobilka BK (2009) The structure and function of Gprotein-coupled receptors. Nature 459: 356-63.

Sánchez MF, Els-Heindl S, Beck-Sickinger AG, Wieneke R, Tampé R (2021) Photoinduced receptor confinement drives ligand-independent GPCR signaling. Science 371 Sánchez MF, Murad F, Gülcüler Balta GS, Martin-Villalba A, García-Sáez AJ, Carrer DC (2018) Early activation of CD95 is limited and localized to the cytotoxic synapse. Febs $j$ 285: $2813-27$. 
Sankaran J, Shi X, Ho LY, Stelzer EH, Wohland T (2010) ImFCS: a software for imaging FCS data analysis and visualization. Opt Express 18: 25468-81.

Schindelin J, Arganda-Carreras I, Frise E, Kaynig V, Longair M, Pietzsch T, Preibisch S, Rueden C, Saalfeld S, Schmid B, Tinevez JY, White DJ, Hartenstein V, Eliceiri K, Tomancak P, Cardona A (2012) Fiji: an open-source platform for biological-image analysis. Nat Methods 9: 676-82.

Schneider CA, Rasband WS, Eliceiri KW (2012) NIH Image to ImageJ: 25 years of image analysis. Nat Methods 9: 671-5.

Schütz GJ, Weghuber J, Lanzerstorfer P, Sevcsik E (2017) Protein Micropatterning Assay: Quantitative Analysis of Protein-Protein Interactions. Methods Mol Biol 1550: 261-70.

Schwille P, Korlach J, Webb WW (1999) Fluorescence correlation spectroscopy with singlemolecule sensitivity on cell and model membranes. Cytometry 36: 176-82.

Scott FL, Stec B, Pop C, Dobaczewska MK, Lee JJ, Monosov E, Robinson H, Salvesen GS, Schwarzenbacher R, Riedl SJ (2009) The Fas-FADD death domain complex structure unravels signalling by receptor clustering. Nature 457: 1019-22.

Sebestyen Z, Prinz I, Déchanet-Merville J, Silva-Santos B, Kuball J (2020) Translating gammadelta $(\gamma \delta)$ T cells and their receptors into cancer cell therapies. Nat Rev Drug Discov 19: 169-84.

Stallaert W, Brüggemann Y, Sabet O, Baak L, Gattiglio M, Bastiaens PIH (2018) Contact inhibitory Eph signaling suppresses EGF-promoted cell migration by decoupling EGFR activity from vesicular recycling. Sci Signal 11

Su X, Ditlev JA, Hui E, Xing W, Banjade S, Okrut J, King DS, Taunton J, Rosen MK, Vale RD (2016) Phase separation of signaling molecules promotes T cell receptor signal transduction. Science 352: 595-9.

Sungkaworn T, Jobin ML, Burnecki K, Weron A, Lohse MJ, Calebiro D (2017) Singlemolecule imaging reveals receptor-G protein interactions at cell surface hot spots. Nature 550: 543-7.

Tang T, Hartig C, Chen Q, Zhao W, Kaiser A, Zhang X, Zhang H, Qu H, Yi C, Ma L, Han S, Zhao $Q$, Beck-Sickinger AG, Wu B (2021) Structural basis for ligand recognition of the neuropeptide $Y \mathrm{Y}(2)$ receptor. Nat Commun 12: 737.

Torres AJ, Wu M, Holowka D, Baird B (2008) Nanobiotechnology and cell biology: microand nanofabricated surfaces to investigate receptor-mediated signaling. Annu Rev Biophys 37: 265-88.

Traub MC, Longsine W, Truskett VN (2016) Advances in Nanoimprint Lithography. Annu Rev Chem Biomol Eng 7: 583-604.

Tsukiyama T, Zou J, Kim J, Ogamino S, Shino Y, Masuda T, Merenda A, Matsumoto M, Fujioka Y, Hirose T, Terai S, Takahashi H, Ishitani T, Nakayama KI, Ohba Y, Koo BK, 
Hatakeyama S (2020) A phospho-switch controls RNF43-mediated degradation of Wnt receptors to suppress tumorigenesis. Nat Commun 11: 4586.

Venkatakrishnan AJ, Deupi X, Lebon G, Tate CG, Schertler GF, Babu MM (2013) Molecular signatures of G-protein-coupled receptors. Nature 494: 185-94.

Walther C, Nagel S, Gimenez LE, Mörl K, Gurevich VV, Beck-Sickinger AG (2010) Ligandinduced internalization and recycling of the human neuropeptide $\mathrm{Y} 2$ receptor is regulated by its carboxyl-terminal tail. J Biol Chem 285: 41578-90.

Wanka L, Babilon S, Kaiser A, Mörl K, Beck-Sickinger AG (2018) Different mode of arrestin3 binding at the human $Y(1)$ and $Y(2)$ receptor. Cell Signal 50: 58-71.

Wawrezinieck L, Rigneault H, Marguet D, Lenne PF (2005) Fluorescence correlation spectroscopy diffusion laws to probe the submicron cell membrane organization. Biophys J 89: 4029-42.

Wootten D, Christopoulos A, Marti-Solano M, Babu MM, Sexton PM (2018) Mechanisms of signalling and biased agonism in G protein-coupled receptors. Nat Rev Mol Cell Biol 19: 638-53.

Ziffert I, Kaiser A, Babilon S, Mörl K, Beck-Sickinger AG (2020) Unusually persistent Ga(i)signaling of the neuropeptide $Y(2)$ receptor depletes cellular $G(i / o)$ pools and leads to a G(i)-refractory state. Cell Commun Signal 18: 49. 
A

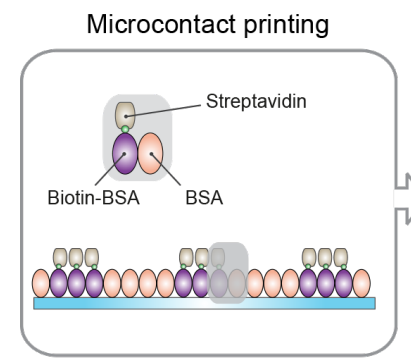

B

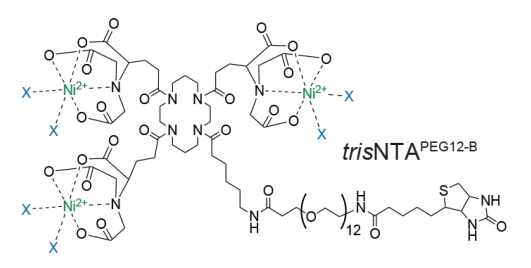

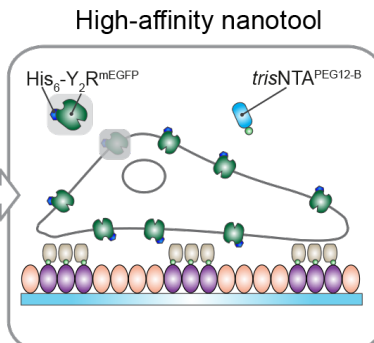

C



E
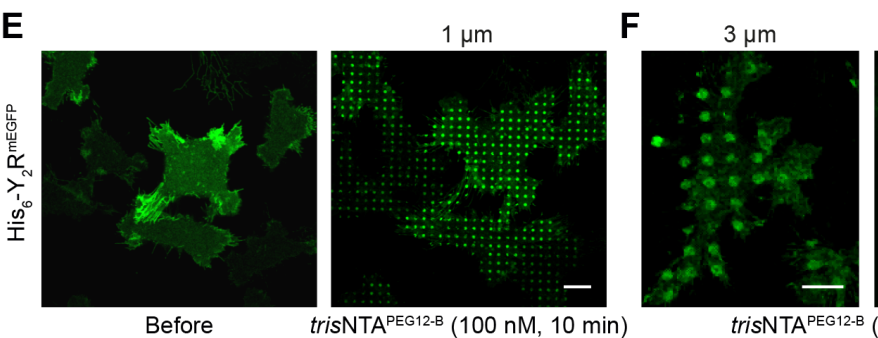
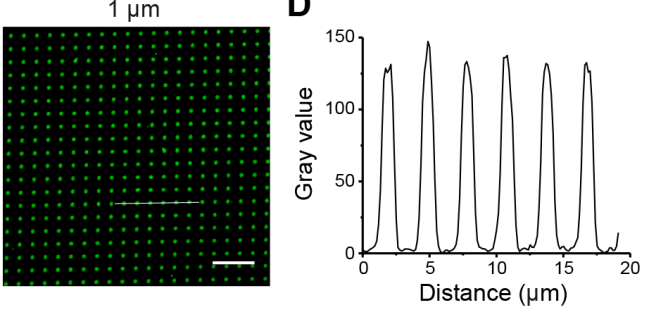

737

\section{Figure 1. High-content ligand-free receptor confinement.}

A Rational of the high-content ligand-free receptor clustering. Matrices prestructured with nanotool trisNTA ${ }^{\mathrm{PEG12-B}}$, His6-tagged receptors in HeLa cells are captured to the

B Chemical structure of the trisNTA ${ }^{\mathrm{PEG12-B}}$.

C Variable size protein patterns generated by further functionalization of SA-matrices with the nanotool followed by incubation with $\mathrm{His}_{6}-\mathrm{GFP}(0.1 \mu \mathrm{M}, 20 \mathrm{~min})$. Images were acquired by confocal laser scanning microscopy.

D Intensity profile of the $1 \mu \mathrm{m}$ pattern (white line in C) reflects high specificity of the

749 E Large-scale cell patterning in living cells occurred after addition of the trisNTA ${ }^{\text {PEG12-B }}$ (100 nM, $10 \mathrm{~min})$.

$751 \mathrm{~F}$ Customized $\mathrm{Y}_{2} \mathrm{R}$ assembly on $3 \mu \mathrm{m}$ and $1 \mu \mathrm{m}$ SA-prestructured matrices. 
bioRxiv preprint doi: https://doi.org/10.1101/2021.12.15.472742; this version posted December $17,2021$. The copyright holder for this

preprint (which was not certified by peer review) is the author/funder, who has granted bioRxiv a license to display the preprint in perpetuity. It is made available under aCC-BY-NC-ND 4.0 International license.

$752 \mathrm{G}$ Intensity profile of the $1 \mu \mathrm{m}$ pattern (white line in $\mathrm{f}$ ) showed an intensity comparable to a 753 soluble His6-tagged protein. Scale bars: $10 \mu \mathrm{m}$. 
A
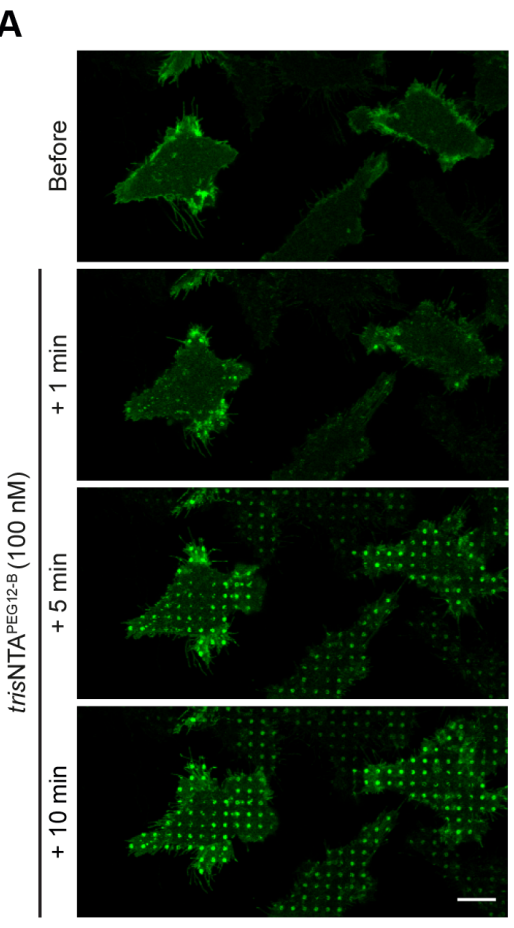

B
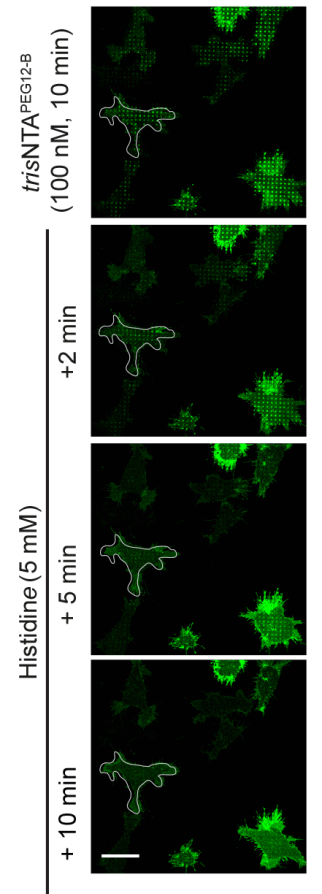

C

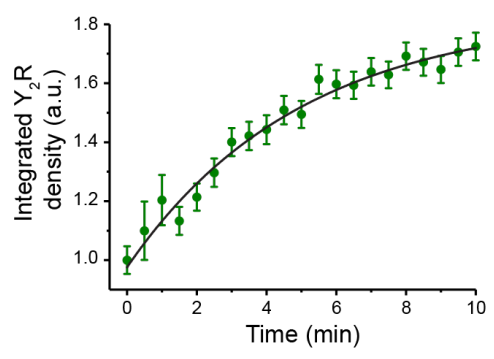

D

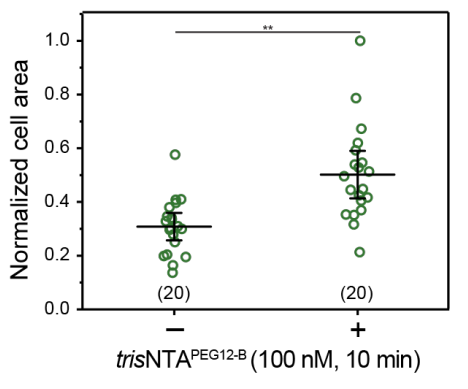

Figure 2. Ligand-independent response triggered by in situ receptor confinement.

A Time-lapse imaging of $Y_{2} R$ assembly. $Y_{2} R$ expressing HeLa cells were allowed to adhere to prestructured SA-matrices for $3 \mathrm{~h}$ and visualized by CLSM in LCIS at $37^{\circ} \mathrm{C}$. Time-lapse images were recorded for 10 min immediately after addition of trisNTA ${ }^{\text {PEG12-B }}(100 \mathrm{nM})$.

B Reversal of the interaction and disassembly of the clusters is demonstrated upon addition of histidine. $Y_{2} R$ expressing cells were allowed to adhere to the SA-matrices for $3 \mathrm{~h}$, and then receptor confinement was induced by addition of trisNTA ${ }^{\text {PEG12-B }}(100 \mathrm{nM})$. Subsequently, cells were incubated with histidine $(5 \mathrm{mM})$ for 2 to $10 \mathrm{~min}$ followed by washing.

C Receptor integrated density in the patterned regions increased mono-exponentially, leading to an assembly rate of $0.20 \pm 0.03 \mathrm{~min}^{-1}$ and $\tau_{1 / 2}=5 \mathrm{~min}$.

D Fast cell spreading upon cluster formation was observed. Cell area analysis before and 10 min after nanotool addition showed a $20 \%$ area increase, confirming an effect of the receptor clusters on cell response. Values for cell area were normalized with respect to the highest value. The mean \pm SD (20 cells) is shown. ${ }^{* *} p \leq 0.01$ for Tukey test. Scale bars: $10 \mu \mathrm{m}$. 
A
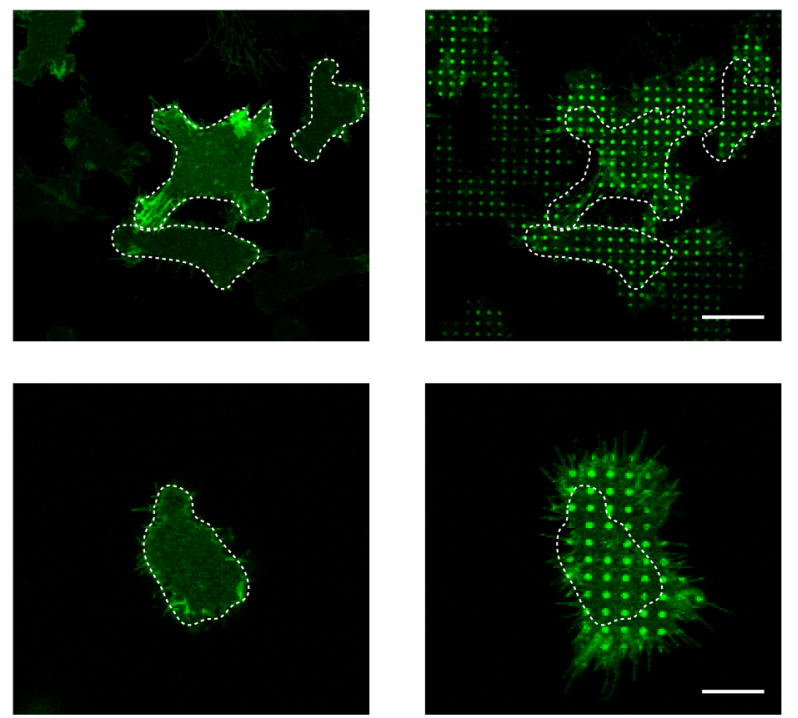

B

Before

trisNTA $^{\text {PEG12-B }}(100 \mathrm{nM}, 10 \mathrm{~min})$

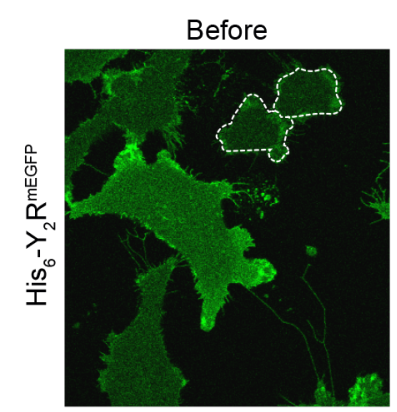

trisNTA PEG12-B

(100 $\mathrm{nM}, 5 \mathrm{~min})$

(1 $\mathrm{nM}, 5 \mathrm{~min})$


C



D

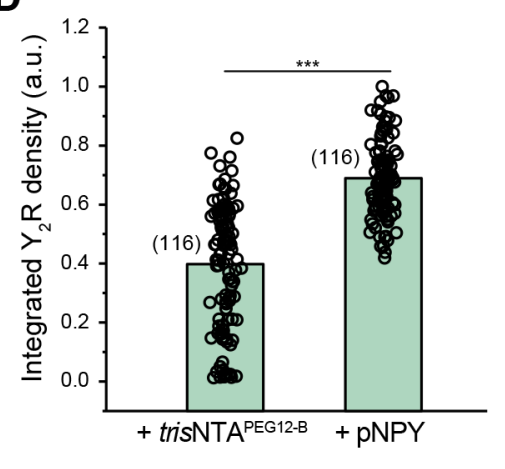

\section{Figure 3. Ligand-free receptor confinement triggers calcium signaling.}


773 A Representative images of $\mathrm{His}_{6}-\mathrm{Y}_{2} \mathrm{R}^{\mathrm{mEGFP}}$ expressing cells over SA-prestructured matrices

774 before and in the presence of trisNTA ${ }^{\mathrm{PEG} 12-\mathrm{B}}$ demonstrated a significant change in cell area.

775 Scale bar: $20 \mu \mathrm{m}$ upper panel, $10 \mu \mathrm{m}$ lower panel.

776 B Representative fluorescence images of the $Y_{2} R$ (upper panel) and color-coded images of

777 the $\mathrm{Ca}^{2+}$ dye (lower panel). $\mathrm{Y}_{2} \mathrm{R}$ expressing cells on SA-prestructured matrices were 778 incubated with BioTracker $609 \mathrm{Red} \mathrm{Ca}^{2+} \mathrm{AM}$ dye $(3 \mu \mathrm{M})$ for $30 \mathrm{~min}$. After rinsing, cells were

779 immediately imaged by CLSM in LCIS at $37^{\circ} \mathrm{C}$. Addition of the nanotool showed a twofold

$780 \quad$ increase in cytosolic calcium.

781 C Analysis of the mean gray value for $\mathrm{Ca}^{2+}$ signal before $\left(\mathrm{F}_{0}\right)$ and upon addition of

782 trisNTA ${ }^{\text {PEG12-B }}(\mathrm{F})$ versus time. Time-lapse images were recorded with $45 \mathrm{~s}$ interval before

783 and after addition of trisNTA ${ }^{\text {PEG12-B }}(100 \mathrm{nM})$ (5 slices z-stack per time-point). ROIs covering

784 the complete cell area were considered. The mean \pm SD (10 cells) is shown. Scale bar:

$785 \quad 10 \mu \mathrm{m}$.

786 D Quantification of receptor integrated density in the nanotool patterned regions showed an 787 increase in the density of the receptors within the clusters after addition of the pNPY. The 788 mean \pm SD is shown (113 $1 \mu \mathrm{m}$ ROI were analyzed). ${ }^{* * *} \mathrm{p} \leq 0.001$ for Tukey test. 

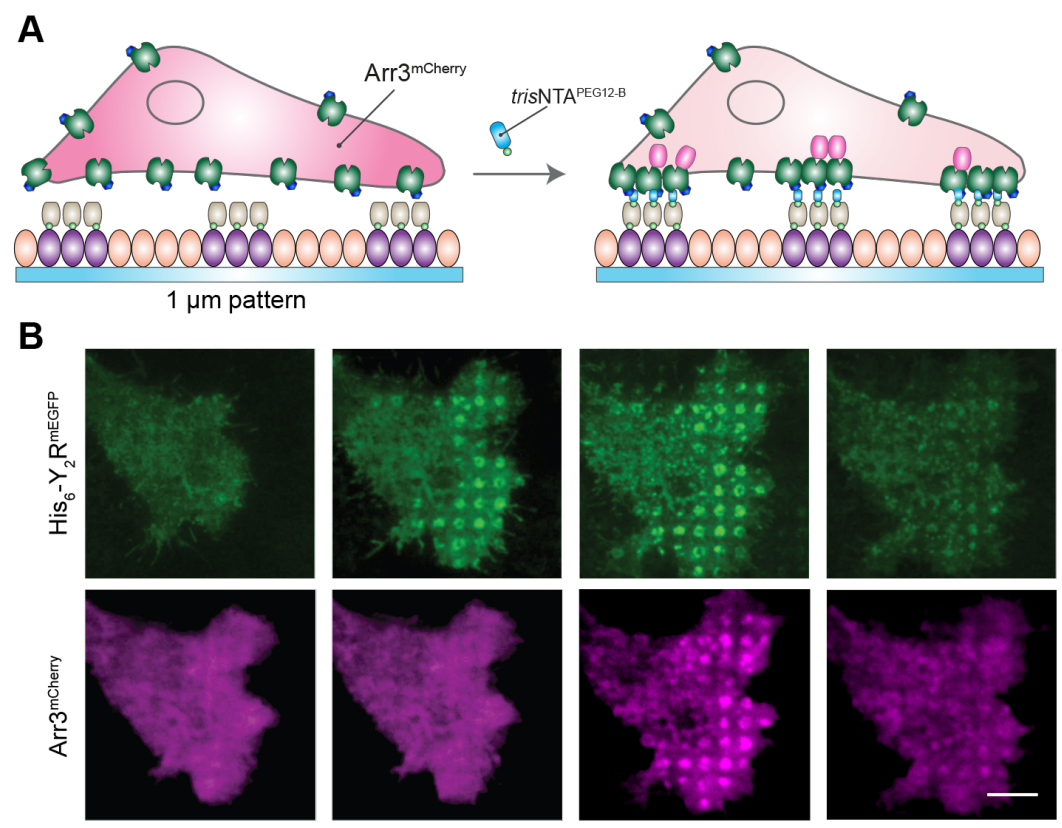

trisNTA ${ }^{\text {PEG } 12: B}, 100 \mathrm{nM}$

pNPY, $10 \mathrm{nM}$

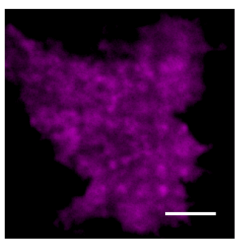

Histidine, $5 \mathrm{mM}$

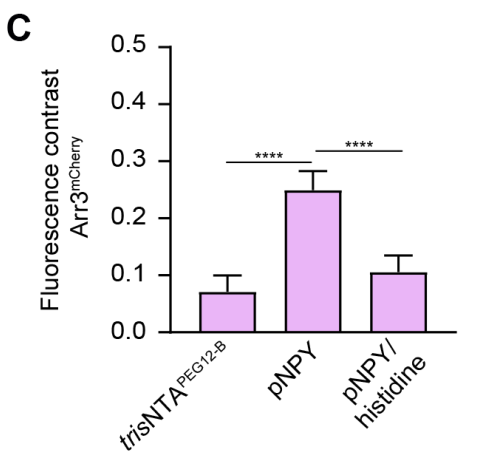

D

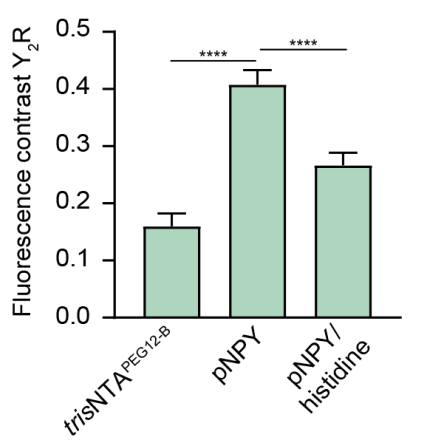

Figure 4. Selective arrestin-3 recruitment upon ligand-induced receptor activation.

A Schematic representation of the experimental set-up. Cells co-expressing $Y_{2} R$ and Arr3 were allowed to adhere to SA-prestructured matrices for $3 \mathrm{~h}$ and visualized by total internal reflection fluorescence (TIRF) microscopy in LCIS at $37^{\circ} \mathrm{C}$.

B Representative TIRF images of cells before and upon addition of trisNTA ${ }^{\text {PEG12-B }}$ (100 nM, $30 \mathrm{~min})$ and subsequent incubation with porcine neuropeptide pNPY (10 nM) and Histidine $(5 \mathrm{mM})$ in LCIS for $30 \mathrm{~min}$ at $37^{\circ} \mathrm{C}$. Scale bar: $5 \mu \mathrm{m}$.

C Fluorescence contrast analysis demonstrated no significant recruitment of Arr3 upon trisNTA $^{\text {PEG12-B }}$ (1.4-fold with respect to the basal signal before, $100 \mathrm{nM}, 30 \mathrm{~min}$ ). Addition of pNPY increased Arr3 signal (3.6-fold, $10 \mathrm{nM}, 30 \mathrm{~min}$ ) confirming co-patterning of the downstream signaling molecule. Subsequent addition of histidine led to a decrease in the signal (2.3-fold, $5 \mathrm{mM}, 30 \mathrm{~min}$ ). Data was normalized with respect to the fluorescence intensity before clustering and it is expressed as the means \pm SEM (60 cells for each

$804 \mathrm{D}$ Quantification of the fluorescence contrast in the patterned regions for $Y_{2} R$ confirmed receptor enrichment upon addition of trisNTA ${ }^{\text {PEG12-B }}$, (2-fold with respect to the basal signal 
bioRxiv preprint doi: https://doi.org/10.1101/2021.12.15.472742; this version posted December $17,2021$. The copyright holder for this preprint (which was not certified by peer review) is the author/funder, who has granted bioRxiv a license to display the preprint in perpetuity. It is made available under aCC-BY-NC-ND 4.0 International license.

806 before, $100 \mathrm{nM}, 30 \mathrm{~min}$ ) which further increased 4-fold upon addition of pNPY (10 nM, 30

$807 \mathrm{~min})$. Histidine addition led to a decrease in the signal (1.7-fold decrease compared to

808 pNPY, $5 \mathrm{mM}, 30 \mathrm{~min}$ ). Data was normalized with respect to the fluorescence intensity

809 before clustering and it is expressed as the means \pm SEM (60 cells for each condition were

810 analyzed). Tukey's multiple comparisons test was applied $\left({ }^{* * *} p \leq 0.001\right)$. 
A

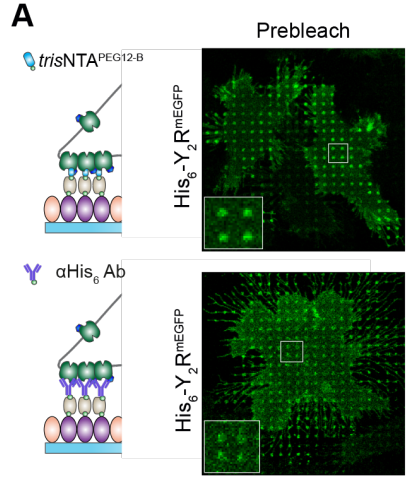

C

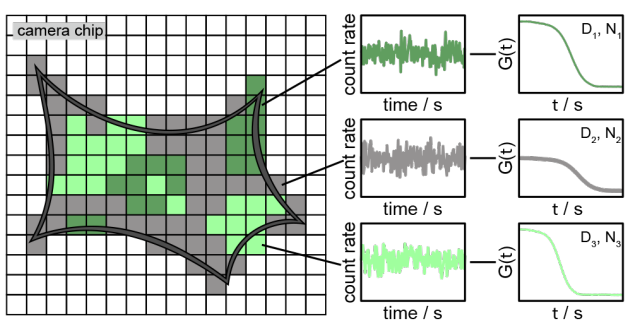

Bleach
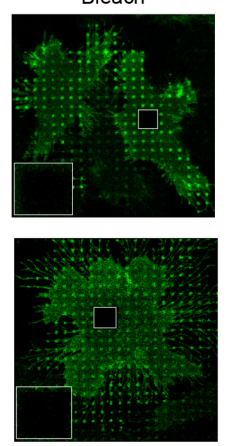

811

\section{Figure 5. Decrease of receptor mobility in confined regions.}

813 A Confocal images of FRAP measurements upon $Y_{2} R$ clustering induced either by the

814 nanotool in situ or by an anti-His 6 antibody. Insets represent the bleached ROls. Fast

815 recovery of the clusters can be detected for the case of the multivalent nanotool.

816

B Quantification of the receptor mobile fraction for cell patterning by the trisNTA ${ }^{\text {PEG12-B }}$ and anti-His 6 antibody demonstrated a significant decrease in the receptor mobile fraction for the antibody matrices suggesting a lower receptor exchange. The mean \pm SD is shown. 9 cells before, 11 cells after trisNTA ${ }^{\text {PEG12-B }}\left(45 \mathrm{x} 1 \mu \mathrm{m}\right.$ ROIs) and 5 cells on anti-His ${ }_{6}$ antibody matrices $\left(13 \times 1 \mu \mathrm{m}\right.$ ROIs) were analyzed. ${ }^{* * *} p \leq 0.001$ for Tukey test.

C imFCS correlates fluorescence intensity fluctuations in single camera pixels with a large degree of statistics, providing accurate diffusion coefficients with high spatial and temporal resolution.

D Widefield image of a ROI at the plasma membrane of a living cell upon addition of the nanotool analyzed by imFCS (left). The analyses of numerous pixels simultaneously provide two-dimensional diffusion data that draw a picture of the mobility of membrane receptors and reveal local differences in the diffusion (right).
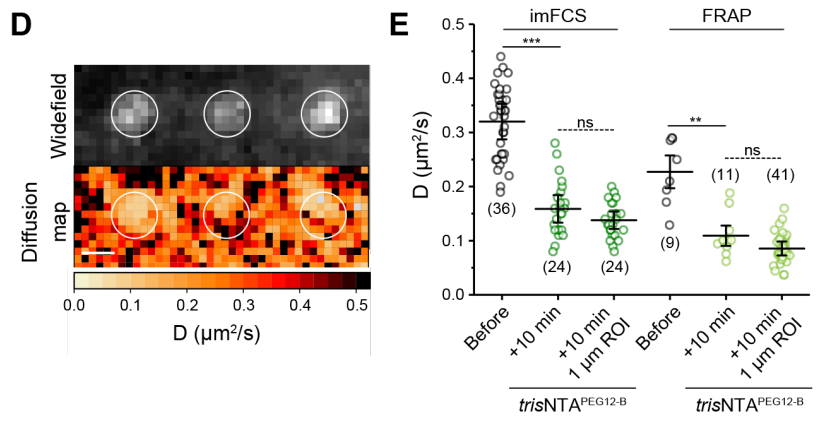
828 E Both techniques demonstrated a decrease in the lateral diffusion of the receptor at the 829 plasma membrane after addition of the nanotool. Analysis of $1 \mu \mathrm{m}$ clusters within the entire

830 ROI led to a further decrease in the lateral diffusion coefficient. For imFCS analyses, two831 sample t-tests $(\alpha=0.05)$ were applied to compare the diffusion coefficients for the different 832 conditions. The mean \pm SD is shown. 36 and 24 cells for the conditions before and after 833 addition of trisNTA ${ }^{\text {PEG12-B }}$ were analyzed. For FRAP, the mean \pm SD is shown (9 cells 834 before, 11 cells after trisNTA ${ }^{\text {PEG12-B }}, 411 \mu \mathrm{m}$ ROls were analyzed). ${ }^{* * *} p \leq 0.001$ for Tukey 835 test. Scale bar: $10 \mu \mathrm{m}(\mathrm{A}), 1 \mu \mathrm{m}(\mathrm{D})$. 


\section{Expanded View Figures}

A

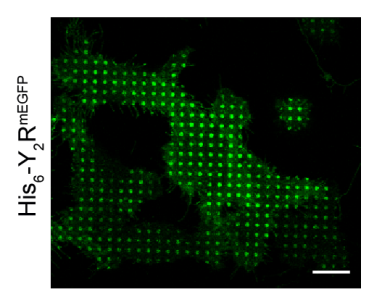

B

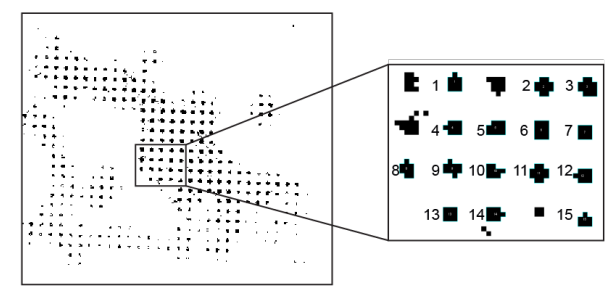

C

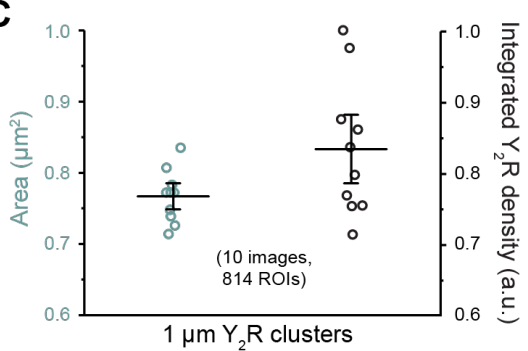

837

Figure EV1. Receptor confinement with high reliability.

839 A Representative confocal image of a cell patterned by trisNTA ${ }^{\text {PEG12-B }}(100 \mathrm{nM})$.

840 B Automatic cluster analysis performed by ImageJ requires a "binary", black and white, 841 image. A threshold range is set to select the objects of interest apart from the background.

842 All pixels in the image whose values lie under the threshold are converted to white and all 843 pixels with values above the threshold are converted to black. Further selection of the 844 clusters according to area and roundness enable a large-scale analysis.

845 C Change in cluster area and integrated density of the receptor within different 96-well plates, 846 different months and cell stocks reflected a reliable and reproducible approach. The 847 average area in the clustered regions $\left(0.77 \pm 0.03 \mu \mathrm{m}^{2}\right)$ and integrated density of ten 848 images in five different experiments (841x ROls of $1 \mu \mathrm{m}$ in total) is shown. Scale bar: $10 \mu \mathrm{m}$. 




Before

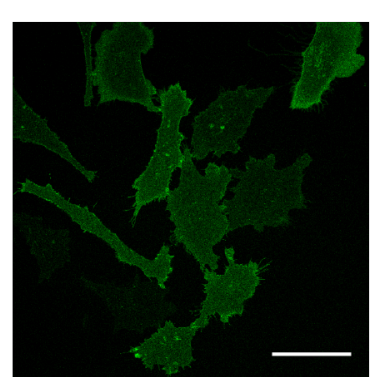

trisNTA ${ }^{\text {PEG12-B }}(100 \mathrm{nM}, 10 \mathrm{~min})$
B

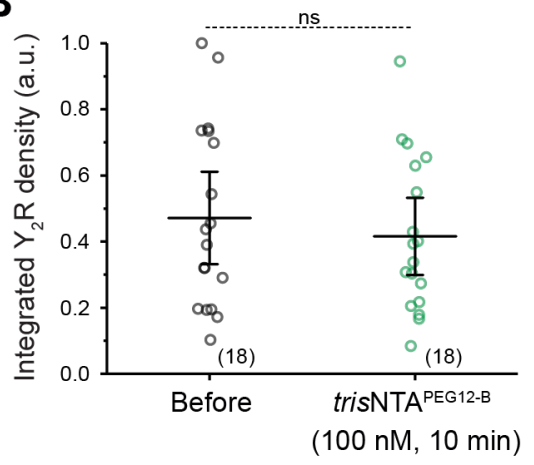

851 Figure EV2. $\mathrm{Y}_{2}$ receptors lacking a His 6 -tag do not cluster in confined areas.

852 A Cells expressing $\mathrm{Y}_{2}$ receptors without $\mathrm{N}$-terminal His ${ }_{6}$-tag over SA-prestructured matrices

853 before and after addition of the nanotool. Within the timeframe of imaging, there was neither

854 a pattern formation nor a change in the integrated receptor density.

855 B Quantification of the integrated $\mathrm{Y}_{2} \mathrm{R}$ density before and after addition of trisNTA ${ }^{\mathrm{PEG} 12-\mathrm{B}}$. The mean \pm SD (18 cells) is shown. ${ }^{* *} p \leq 0.01$ for Tukey test. Scale bar: $50 \mu \mathrm{m}$. 
A

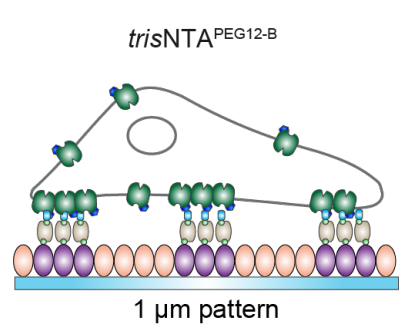

C



$1 \mu \mathrm{m}$ pattern
$\mathrm{His}_{6}-\mathrm{Y}_{2} \mathrm{R}^{\mathrm{mEGFP}}$
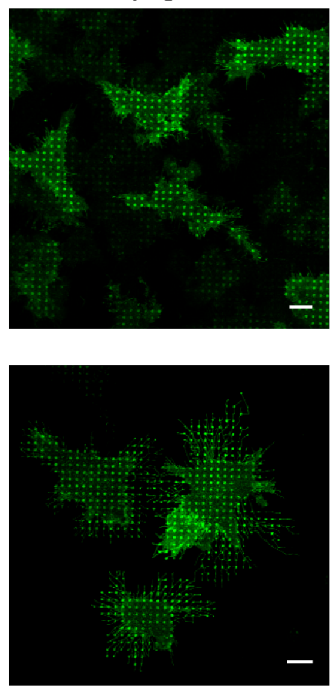

B

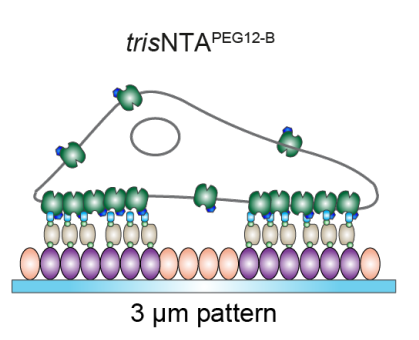

D
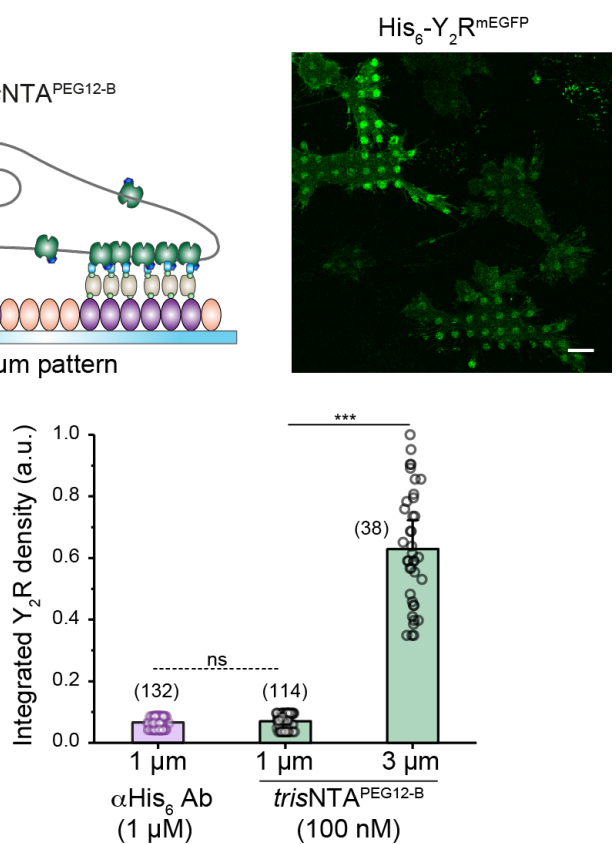

Figure EV3. Receptor density correlates with the area of the prestructured regions.

859 A,B BSA-prestructured matrices (1 $\mu \mathrm{m}, \mathrm{A}$ or $3 \mu \mathrm{m}, \mathrm{B})$ were stepwise functionalized with biotin-

860 BSA and SA. $Y_{2} R$ expressing HeLa cells were allowed to adhere to the functionalized matrix

861 for $3 \mathrm{~h}$ and immediately imaged by CLSM in live-cell imaging solution (LCIS) at $37^{\circ} \mathrm{C}$.

862 Addition of trisNTA ${ }^{\mathrm{PEG} 12-\mathrm{B}}(100 \mathrm{nM})$ led to in situ receptor assembly.

863 C 1 um BSA-prestructured matrices were stepwise functionalized with biotin-BSA, SA, and a

864 biotinylated anti-His 6 antibody ( $\left.a \mathrm{His}_{6} \mathrm{Ab}\right) . \mathrm{Y}_{2} \mathrm{R}$ expressing cells were allowed to adhere to

865 the functionalized matrix for $3 \mathrm{~h}$ and immediately imaged by CLSM in LCIS at $37^{\circ} \mathrm{C}$.

866 D Quantification of the receptor integrated density. In situ receptor confinement by

867 trisNTA ${ }^{\text {PEG12-B }}$ resulted in a receptor density, which is comparable to cells in contact with

868 prestructured antibodies. For the $3 \mu \mathrm{m}$ patterns, receptor density correlated with pattern

869 area. The mean \pm SD (38 to $132 x$ ROls of $1 \mu \mathrm{m})$ is shown. ${ }^{* *} p \leq 0.001$ for Tukey test. Scale

$870 \quad$ bars: $10 \mu \mathrm{m}$. 
A

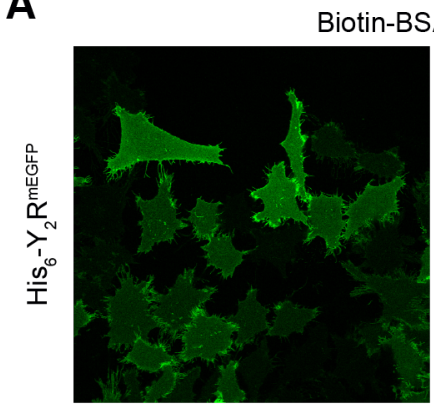

Before

C

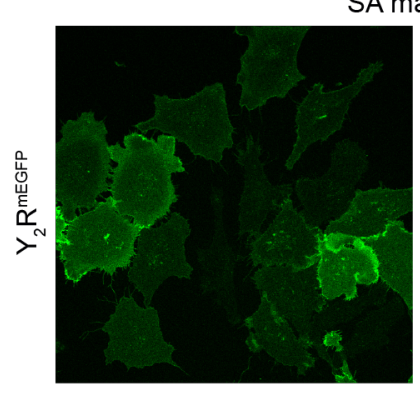

Before

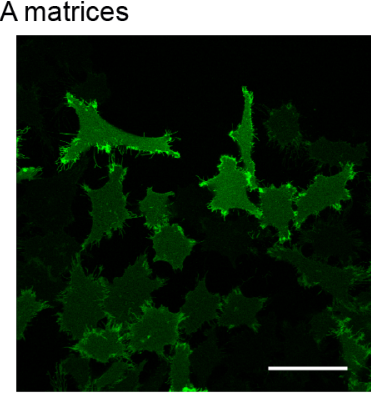

trisNTA $^{\text {PEG12-B }}(100 \mathrm{nM}, 10 \mathrm{~min})$

A matrices
B
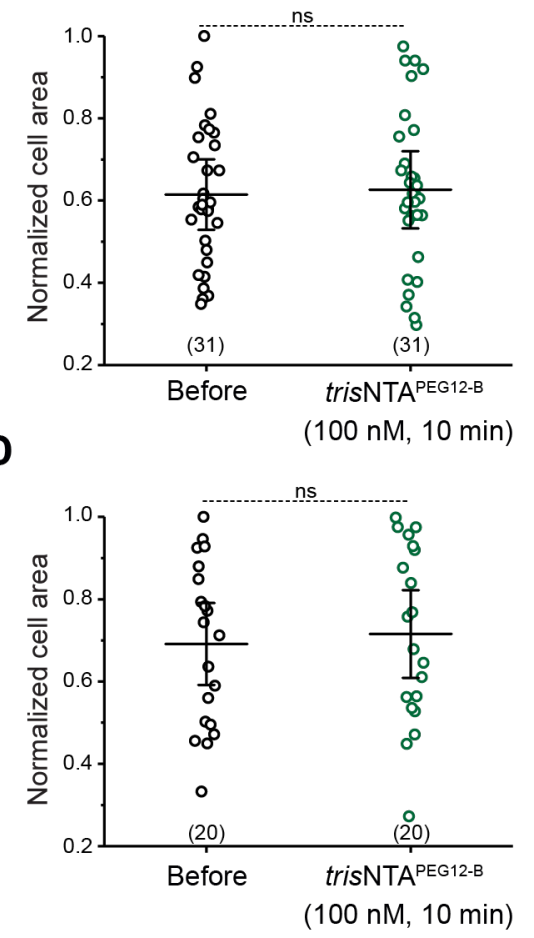

872 Figure EV4. Changes in cell motility are exclusively triggered upon receptor clustering.

873 A,B Confocal images of cells expressing His ${ }_{6}$-tagged $Y_{2} R$ on matrices which do not contain

874 SA but only biotin-BSA. Addition of the trisNTA ${ }^{\text {PEG12-B }}$ nanotool confirms no effect on cell spreading and motility as shown in the quantification of the cell area $(B)$. The mean \pm SD

$876 \quad$ (31 cells) is shown. ${ }^{* *} p \leq 0.01$ for Tukey test.

877 C Confocal images of cells expressing $\mathrm{Y}_{2}$ receptors lacking the $\mathrm{His}_{6}$-tag on SA-matrices do

878 not present significant changes in cells spreading upon addition of the nanotool.

879 D Quantification of the cell area before and after addition of trisNTA ${ }^{\text {PEG12-B }}(100 \mathrm{nM})$. Values

880 for cell area were normalized with respect to the highest value. The mean \pm SD (20 cells)

881 is shown. ${ }^{* *} \mathrm{p} \leq 0.01$ for Tukey test. Scale bar: $50 \mu \mathrm{m}$. 
A


trisNTA ${ }^{\text {PEG12-B }}$

(100 $\mathrm{nM}, 5 \mathrm{~min})$


B

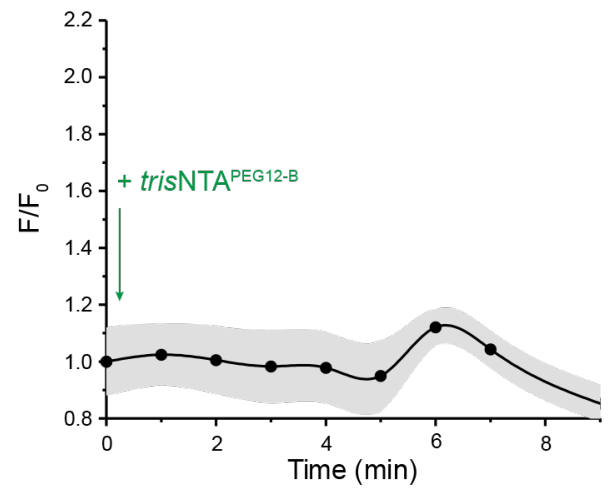

883 Figure EV5. Calcium signaling is a specific response upon clustering.

884 A Representative fluorescence images of the $Y_{2} R$ (upper panel) and color-coded images of the $\mathrm{Ca}^{2+}$ dye (lower panel). $\mathrm{Y}_{2} \mathrm{R}$ expressing cells over prestructured matrices in absence of streptavidin were incubated with BioTracker $609 \mathrm{Red} \mathrm{Ca}^{2+} \mathrm{AM}$ dye $(3 \mu \mathrm{M})$ for $30 \mathrm{~min}$. After rinsing, cells were immediately imaged by CLSM in LCIS at $37^{\circ} \mathrm{C}$. Addition of trisNTA ${ }^{\text {PEG12- }}$

${ }^{B}$ showed neither clustering nor change in cytosolic calcium. Scale bar: $10 \mu \mathrm{m}$

$\mathrm{B}$ Analysis of the mean gray value for $\mathrm{Ca}^{2+}$ signal before $\left(\mathrm{F}_{0}\right)$ and upon addition of $\operatorname{trisNTA}^{\mathrm{PEG12-B}}(\mathrm{F})$ versus time. Time-lapse images were recorded with $45 \mathrm{~s}$ interval before and after addition of trisNTA ${ }^{\text {PEG12-B }}(100 \mathrm{nM})$ (5 slices z-stack per time-point). ROIs covering the complete cell area were considered. The mean \pm SD (10 cells) is shown. 
A

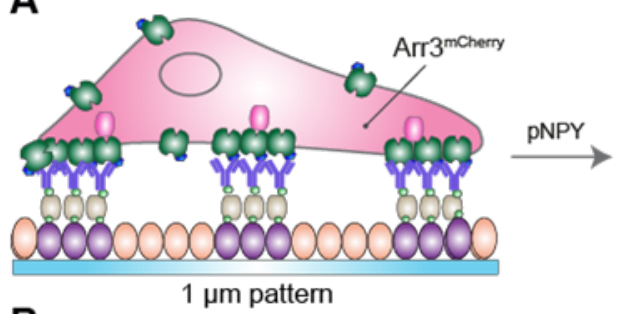

B
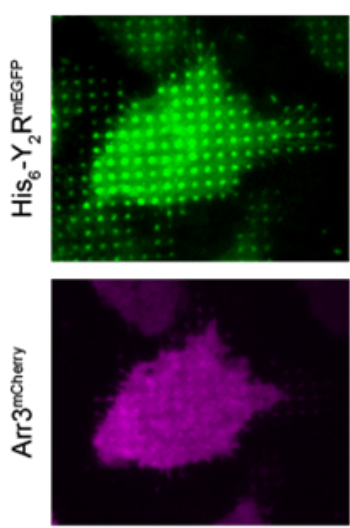

$\mathrm{aHis}_{6} \mathrm{Ab}$ patterning


pNPY

(10 $\mathrm{nM},+15 \mathrm{~min})$


pNPY

$(10 \mathrm{nM},+30 \mathrm{~min})$
C

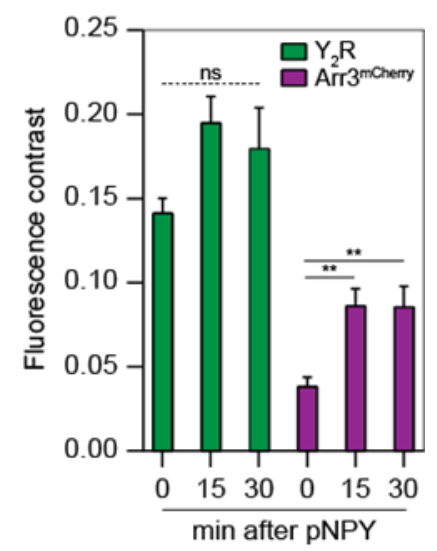

894 Figure EV6. Arrestin-3 recruitment on antibody-confined regions.

895 A Schematic representation of the experimental set-up. Cells co-expressing $Y_{2} R$ and Arr3 were allowed to adhere to anti-His 6 antibody prestructured matrices for $3 \mathrm{~h}$ and visualized by total internal reflection fluorescence (TIRF) microscopy in LCIS at $37^{\circ} \mathrm{C}$.

898 B Representative TIRF images of cells before and upon addition of pNPY (10 nM) in LCIS for $89930 \mathrm{~min}$ at $37^{\circ} \mathrm{C}$. Scale bar: $10 \mu \mathrm{m}$.

900 C Quantification of the fluorescence contrast in the $Y_{2} R$-patterned regions showed no 901 significant change in receptor intensity yet a recruitment of Arr3 upon addition of pNPY 902 (twofold). Data are expressed as the means \pm SEM (30 cells for each condition were analyzed). Tukey’s multiple comparisons test was applied $\left({ }^{* *} p \leq 0.01\right)$. 
A

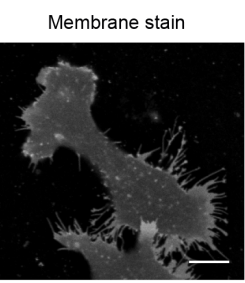

C
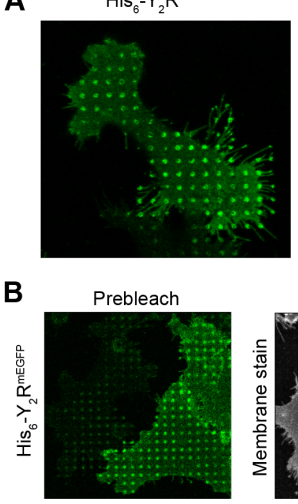

Prebleach
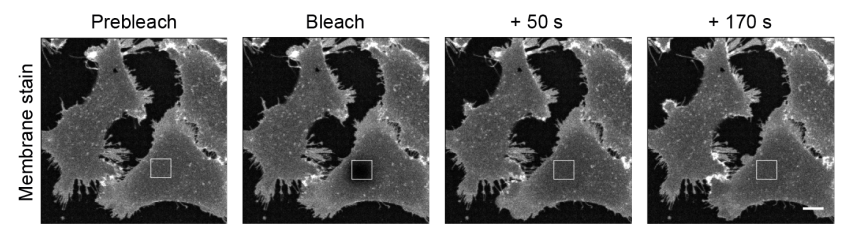

D

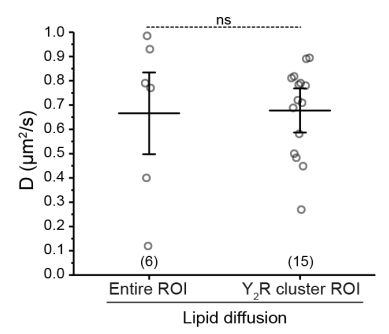

E

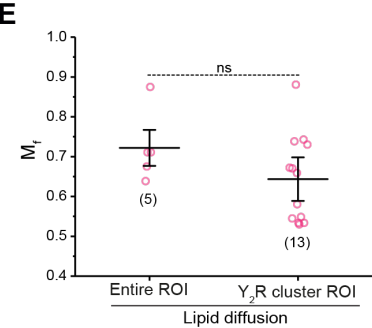

Figure EV7. Lipid localization and dynamics after receptor confinement.

906 A Live-cell plasma membrane staining was performed 15 min after $Y_{2} R$ assembly in living cells. $5 \mu \mathrm{g} / \mathrm{ml}$ CellMask staining solution was incubated for $5 \mathrm{~min}$ at $37^{\circ} \mathrm{C}$ and washed with LCIS before visualization. Lipid distribution is not affected by receptor confinement as shown by the homogeneous staining of the membrane.

910 B Representative confocal images of FRAP measurements for the lipid dye. An image of the

911 receptor channel confirmed the presence of the pattern.

912 C FRAP recovery for the lipid dye measured in the entire rectangular $\mathrm{ROI}$ or at the $\mathrm{Y}_{2} \mathrm{R}$ cluster

913 spots (region selected based on the receptor channel image) demonstrated a rapid 914 recovery for the lipids.

915 D The analysis did not show any differences in lipid diffusion coefficients for the entire

916 rectangular $\mathrm{ROI}$ or at the $1 \mu \mathrm{m}$ clustered regions $\left(D_{\text {entire } \mathrm{ROI}}=0.66 \pm 0.10 \mu \mathrm{m}^{2} / \mathrm{s}\right.$ and $D_{\text {spots }}=$

$\left.917 \quad 0.67 \pm 0.17 \mu \mathrm{m}^{2} / \mathrm{s}\right)$. The mean \pm SD (6 cells, $15 \times 1 \mu \mathrm{m}$ ROls $)$ is shown. ${ }^{* *} \mathrm{p} \leq 0.01$ for Tukey 918 test.

919 E E Quantification of the mobile fraction $\left(M_{\mathrm{f}}\right)$ for FRAP measurements of the lipid dye reflected 920 no significant difference. The mean \pm SD ( 5 cells, $14 \times 1 \mu \mathrm{m}$ ROls $)$ is shown. ${ }^{* *} p \leq 0.01$ for Tukey test. Scale bars: $10 \mu \mathrm{m}$. 


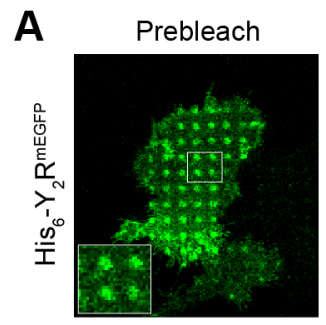

B
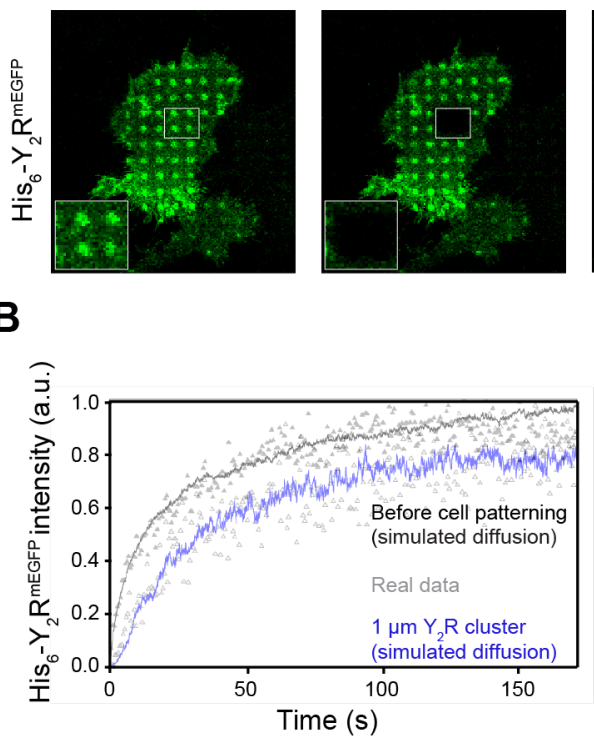

$+50 \mathrm{~s}$

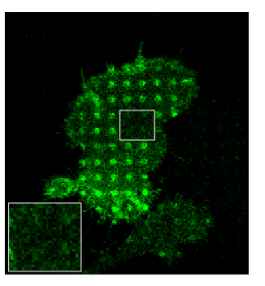

C

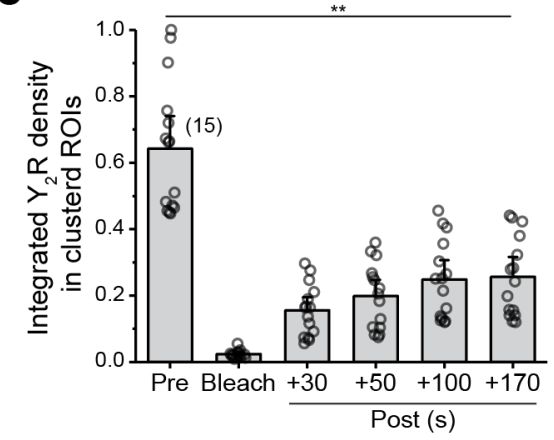

\section{Figure EV8. Dynamic receptor exchange in confined clusters.}

924 A Representative confocal images of FRAP measurements for $\mathrm{Y}_{2} \mathrm{R}$ expressing cells on SA-

925 prestructured matrices 10 min after addition of the nanotool.

926 B FRAP recovery curves reflecting the entire bleached area or an analysis performed only in

927 the clustered $1 \mu \mathrm{m}$ regions. The analysis is based on a simulation approach which fits a

928 computer-simulated recovery to actual recovery data of a FRAP series and determines the

929 diffusion coefficient regardless of bleaching geometry.

930 C Quantification of the receptor density in the confined regions showed $50 \%$ recovery

931 indicating a high exchange rate. The mean \pm SD (6 cells, $15 \times 1 \mu \mathrm{m}$ ROls analyzed) is

932 shown. ${ }^{* *} p \leq 0.01$ for Tukey test. Scale bar: $10 \mu \mathrm{m}$. 
A

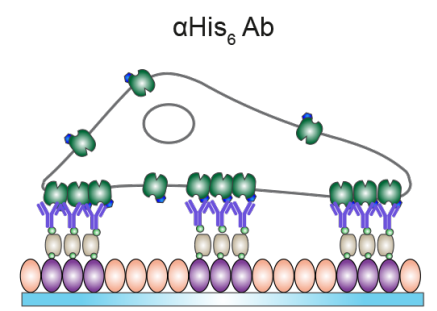

$1 \mu \mathrm{m}$ pattern
B

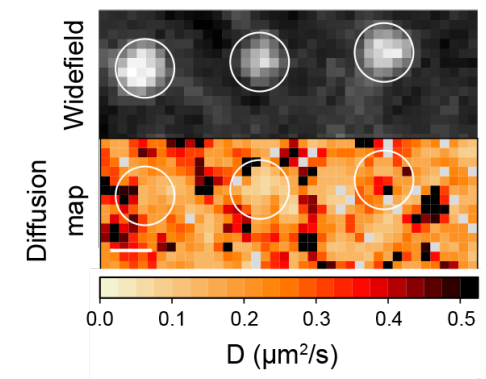

C

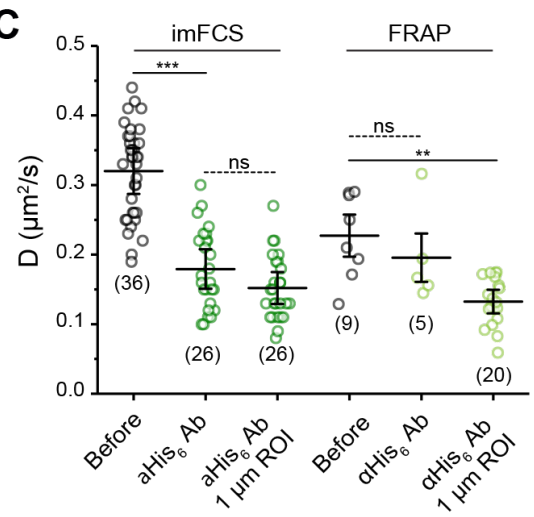

934 Figure EV9. Receptor mobility on antibody structured matrices.

935 A Scheme representing the experimental set-up.

936 B Representative widefield image (left) of a ROI at the plasma membrane of a living cell

937 grown on prestructured matrices with an anti-His 6 antibody ( $\alpha \mathrm{His}_{6} \mathrm{Ab}$ ) analyzed by imFCS

938 and the derived two-dimensional diffusion map (right).

939 C Lateral diffusion of the receptor analyzed by FRAP and imFCS. Both techniques

940 demonstrated a decrease in $\mathrm{D}$ at the plasma membrane $\left(D_{\text {before }}=0.32 \pm 0.06 \mu \mathrm{m}^{2} / \mathrm{s}\right.$ and

$941 \quad 0.25 \pm 0.08 \mu \mathrm{m}^{2} / \mathrm{s} ; D_{\text {anti-His } 6 \mathrm{Ab}}=0.18 \pm 0.06$ and $0.19 \pm 0.06 \mu \mathrm{m}^{2} / \mathrm{s}$ for $\mathrm{imFCS}$ and FRAP

942 respectively), concurring with the values obtained for the measurements upon addition of

943 the nanotool. Analysis of clustered regions $(1 \mu \mathrm{m})$ within the selected ROls led to a further

944 decrease in the diffusion coefficient $\left(D_{\text {spots }}=0.15 \pm 0.05 \mu \mathrm{m}^{2} / \mathrm{s}\right.$ and $0.13 \pm 0.03 \mu \mathrm{m}^{2} / \mathrm{s}$ for

945 imFCS and FRAP, respectively). For imFCS measurements, two-sample t-tests $(\alpha=0.05)$

946 were applied to compare the diffusion coefficients for the different conditions $\left({ }^{* * *} p \leq 0.001\right)$.

947 The mean \pm SD is shown. 36 and 26 cells for the conditions before and after addition of

948 anti-His 6 antibody were analyzed. For FRAP, the mean \pm SD is shown. Here, 9 cells before,

9495 cells after addition of anti-His 6 antibody, $20 x$ ROls were examined. ${ }^{* *} p \leq 0.01$ for Tukey

950 test. Scale bar: $1 \mu \mathrm{m}$. 

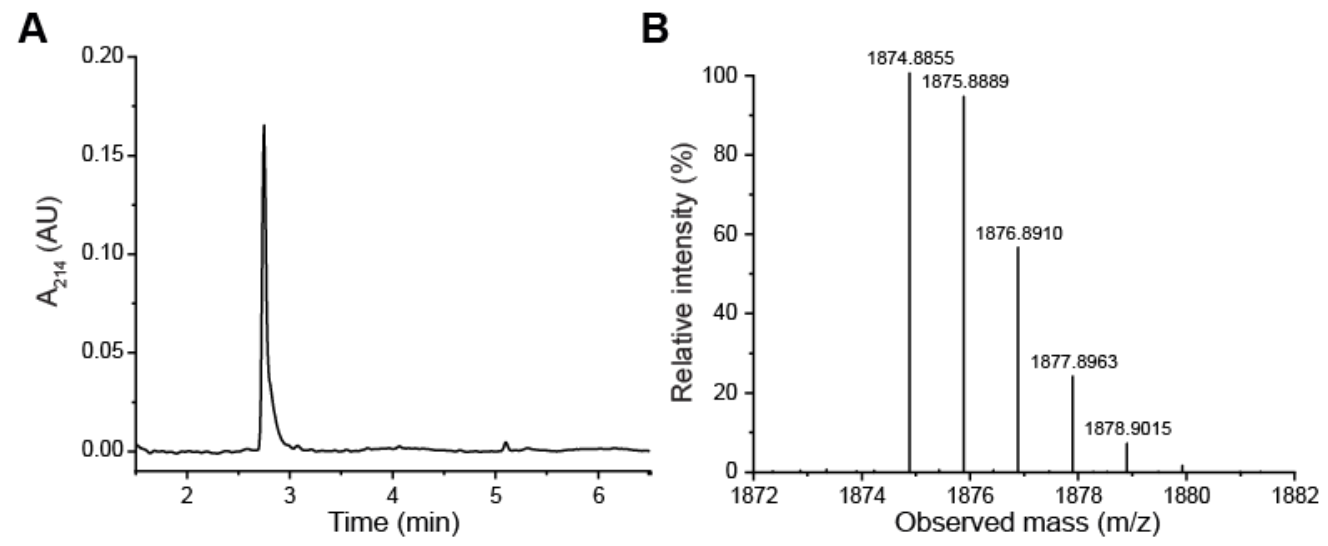

952 Figure EV10. Multivalent nanotool trisNTA ${ }^{\mathrm{PEG} 12-\mathrm{B}}$ analyzed by LC-MS.

953 A trisNTA ${ }^{\mathrm{PEG} 12-\mathrm{B}}$ chromatogram reflecting the purity of the synthesized nanotool.

954 B LC-MS of trisNTA ${ }^{\text {PEG12-B }}$, yielding the experimental mass (Mexp.) of $1874.85 \mathrm{Da}\left(\mathrm{M}_{\text {theor. }}=\right.$ 1873.90 Da). 